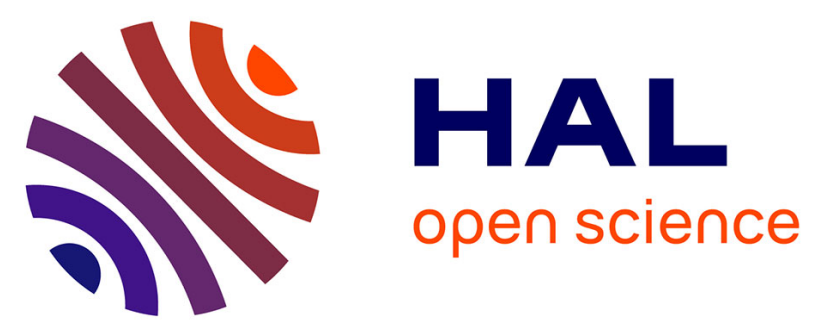

\title{
Trench-parallel spreading ridge subduction and its consequences for the geological evolution of the overriding plate: Insights from analogue models and comparison with the Neogene subduction beneath Patagonia
}

Méline Salze, Joseph Martinod, Benjamin Guillaume, Jean-Jacques Kermarrec, Matias C Ghiglione, Christian Sue

\section{- To cite this version:}

Méline Salze, Joseph Martinod, Benjamin Guillaume, Jean-Jacques Kermarrec, Matias C Ghiglione, et al.. Trench-parallel spreading ridge subduction and its consequences for the geological evolution of the overriding plate: Insights from analogue models and comparison with the Neogene subduction beneath Patagonia. Tectonophysics, 2018, 737, pp.27-39. 10.1016/j.tecto.2018.04.018 . insu-01785447

HAL Id: insu-01785447

https://hal-insu.archives-ouvertes.fr/insu-01785447

Submitted on 4 May 2018

HAL is a multi-disciplinary open access archive for the deposit and dissemination of scientific research documents, whether they are published or not. The documents may come from teaching and research institutions in France or abroad, or from public or private research centers.
L'archive ouverte pluridisciplinaire HAL, est destinée au dépôt et à la diffusion de documents scientifiques de niveau recherche, publiés ou non, émanant des établissements d'enseignement et de recherche français ou étrangers, des laboratoires publics ou privés. 


\section{Accepted Manuscript}

Trench-parallel spreading ridge subduction and its consequences for the geological evolution of the overriding plate: Insights from analogue models and comparison with the Neogene subduction beneath Patagonia

Méline Salze, Joseph Martinod, Benjamin Guillaume, JeanJacques Kermarrec, Matias C. Ghiglione, Christian Sue

PII: S0040-1951(18)30161-6

DOI: doi:10.1016/j.tecto.2018.04.018

Reference: TECTO 127830

To appear in: Tectonophysics

Received date: 9 November 2017

Revised date: 28 March 2018

Accepted date: 24 April 2018

Please cite this article as: Méline Salze, Joseph Martinod, Benjamin Guillaume, JeanJacques Kermarrec, Matias C. Ghiglione, Christian Sue, Trench-parallel spreading ridge subduction and its consequences for the geological evolution of the overriding plate: Insights from analogue models and comparison with the Neogene subduction beneath Patagonia. The address for the corresponding author was captured as affiliation for all authors. Please check if appropriate. Tecto(2017), doi:10.1016/j.tecto.2018.04.018

This is a PDF file of an unedited manuscript that has been accepted for publication. As a service to our customers we are providing this early version of the manuscript. The manuscript will undergo copyediting, typesetting, and review of the resulting proof before it is published in its final form. Please note that during the production process errors may be discovered which could affect the content, and all legal disclaimers that apply to the journal pertain. 
Trench-parallel spreading ridge subduction and its consequences for the geological evolution of the overriding plate: insights from analogue models and comparison with the Neogene subduction beneath Patagonia

Méline Salze $^{1}$, Joseph Martinod ${ }^{2}$, Benjamin Guillaume ${ }^{3}$, Jean-Jacques Kermarrec ${ }^{3}$, Matias C. Ghiglione ${ }^{4}$, Christian Sue ${ }^{1}$

Corresponding author: meline.salze@univ-fcomte.fr

1) Chrono-environnement, CNRS-UMR6249, Université de Bourgogne-Franche-Comté, 16 route de Gray, 25030 Besançon cedex, France

${ }^{2)}$ ISTerre, Université de Savoie Mont-Blanc, 73376 Le Bourget du Lac cedex, France

3) Univ Rennes, CNRS, Géosciences Rennes - UMR 6118, F-35000 Rennes, France

4) Instituto de Estudios Andinos IDEAN (Universidad de Buenos Aires - CONICET), Buenos Aires, Argentina. 


\section{Abstract}

A series of 3-D asthenospheric-scale analogue models have been conducted in the laboratory in order to simulate the arrival of a spreading ridge at the trench and understand its effect on plate kinematics, slab geometry, and on the deformation of the overriding plate. These models are made of a two-layered linearly viscous system simulating the lithosphere and asthenosphere. We reproduce the progressive decrease in thickness of the oceanic lithosphere at the trench. We measure plate kinematics, slab geometry and upper plate deformation. Our experiments reveal that the subduction of a thinning plate beneath a freely moving overriding continent favors a decrease of the subduction velocity and an increase of the oceanic slab dip. When the upper plate motion is imposed by lateral boundary conditions, the evolution of the subducting plate geometry largely differs depending on the velocity of the overriding plate: the larger its trenchward velocity, the smaller the superficial dip of the oceanic slab. A slab flattening episode may occur resulting from the combined effect of the subduction of an increasingly thinner plate and the trenchward motion of a fast overriding plate. Slab flattening would be marked by an increase of the distance between the trench and the volcanic arc in nature. This phenomenon may explain the reported Neogene eastward motion of the volcanic arc in the Southern Patagonian that occurred prior to the subduction of the Chile Ridge.

\section{Highlights:}

-We model the subduction of a spreading ridge parallel to the trench.

-In the case where the upper plate motion is free, subduction and trench retreat rates slow down.

-This decreasing velocity is accompanied by an increase of the slab dip.

-In the case where the trenchward upper plate motion is imposed, the slab flattens beneath the overriding plate.

-The Miocene eastward migration of the magmatic arc in Patagonia may have resulted from the westward motion of South America when the Chile ridge approached the trench.

Key words: Analogue modeling, subduction, oceanic ridge, slab pull force, lithosphere, 
Southernmost Andes, Patagonia.

\section{Introduction}

Subduction is primarily driven by the negative buoyancy of the oceanic lithosphere (i.e. slab pull force) that depends on its age and thickness (e.g. Spence, 1987). Oceanic plates, indeed, become denser than the asthenosphere when they get older than $\sim 10 \mathrm{Ma}$ (Cloos, 1993). The buoyancy of the subducting oceanic plate depends on the age of the oceanic floor, the thickness of the oceanic crust and also the degree of eclogite formation in the sinking crust (Spence, 1987). Bathymetric highs on old ocean floors generally correspond to thick crustal segments, marking an area of larger average buoyancy of the plate. Many analytical (Chung and Kanamori, 1978), numerical (e.g., Geist et al., 1993; Van Hunen et al., 2004; Mason et al., 2010; Arrial and Billen, 2013) and analogue models (Martinod et al., 2005; 2013) describe the effect of aseismic ridges or oceanic plateaus on the process of subduction. These models show that oceanic ridges and thick plateaus may have large consequences on uplift, tectonic, sedimentary, and erosional processes in the overriding plate. They also show that the dynamics of subduction and the dip of the subducting slab may be largely modified by density variations of the oceanic plate. Boundary conditions that apply on the subducting and overriding plates together with density variations may also modify overall plates kinematics, including subduction velocity.

The slab pull force largely depends on the subducting plate volume (Spence, 1987). Analogue models cited above consider the effect of varying slab pull on subduction, but they generally model passive ridges, i.e. oceanic subduction zones in which the thickness of the subducting lithosphere remains essentially unchanged (i.e. constant volume). In this paper, we focus on the subduction of active spreading ridges, i.e. subduction zones in which the thickness of the oceanic plate at trench decreases with time. We present simple analogue models using viscous materials to explore the influence of the arrival of an increasingly thinner plate at the trench on subduction dynamics. How does the decreasing thickness of the subducting plate and the associated decreasing slab-pull force modify the geometry of the slab? How does it change the velocity of subduction and the forces that apply on the overriding plate? How does the interaction with the upper plate influence the process of ridge subduction? Finally, we compare our models with the Chile spreading ridge subduction that occurred during the Miocene beneath Southern Patagonia. The adopted experimental set-up in which the velocity of the plates is largely controlled by far-field boundary conditions is 
particularly relevant to study this example of ridge subduction, as will be explained below. We propose that ridge subduction could explain the Miocene spatial migration of the locus of arc magmatism in this region.

\section{Models set-up}

We perform 3-D analogue models simulating the subduction of an oceanic ridge beneath a continental plate. The experimental procedure is close to that used by Funiciello et al. (2004), Heuret et al. (2007) and Espurt et al. (2008). We use Newtonian viscous materials within a Plexiglas tank $\left(100 \times 100 \times 10 \mathrm{~cm}^{3}\right)$ to reproduce the subduction of an oceanic lithosphere in the upper mantle (Fig. 1).

Plates are modeled using PDMS silicone (Polydimethylsiloxane Silicone) mixed with iron fillers to increase and tune their densities. They initially float above a glucose syrup layer modeling the sub-lithospheric upper mantle (Fig. 1). We vary the density of the silicone putties to reproduce the different lithosphere buoyancies (see Table 1 for the description of the physical parameters of the experiments). The oceanic lithosphere has a negative buoyancy of $-91 \mathrm{~kg} / \mathrm{m}^{3}$ on average while the continental lithosphere has an average positive buoyancy of $+92 \mathrm{~kg} / \mathrm{m}^{3}$. The bottom of the Plexiglas tank simulates the $660 \mathrm{~km}$-deep upper/lower mantle discontinuity. We assume that this boundary acts as an impermeable barrier where the slab remains temporarily stalled for the adopted experimental timescale (Funiciello et al., 2003). The thickness of the glucose syrup layer modeling the upper mantle is $100 \mathrm{~mm}$, which imposes the length ratio $\left(\mathrm{L}^{*}=\mathrm{L}_{\mathrm{M}} / \mathrm{L}_{\mathrm{N}} \sim 1.510^{-7}\right)$ between the models and the natural system (see Table 2 presenting the parameters used for the scaling of these experiments).

To model the subduction of an oceanic ridge segment parallel to the trench and mimic the age-dependence thickness of an oceanic lithosphere, we progressively diminish the thickness of the silicone plate representing the oceanic lithosphere. We model old oceanic lithosphere, far from the ridge using a constant $12 \mathrm{~mm}$-thick silicone plate. Plate thickness decreases linearly up to $3 \mathrm{~mm}$ in the $200 \mathrm{~mm}$ segment closer to the ridge (Figs. 1 and 2). This trenchperpendicular profile is a simplification of the half-space cooling model that approximates the increasing thickness of an oceanic plate with distance from an active ridge accommodating $7.5 \mathrm{~cm} / \mathrm{yr}$ of plate divergence. This velocity approximately corresponds to the average divergence velocity between the Antarctic and Nazca/Farallon plates for the last 40 My. It is 
slightly higher than the mean divergence rate of all the present-day active spreading ridges ( $~ 5 \mathrm{~cm} / \mathrm{yr}$; Conrad and Lithgow-Bertelloni, 2007).

The subduction process is initiated manually by pushing the leading edge of the oceanic plate to a depth of $\sim 3 \mathrm{~cm}$ inside the glucose syrup. Subduction is then driven by the negative buoyancy of the slab. At the end of the experiment, the thinner part of the dense silicone plate progressively subducts until it is entirely consumed into the subduction zone. The role of thermal convection is neglected assuming that the flow within the syrup is only generated by plate motion and subduction. Moreover, the system is isothermal, which implies that the density contrast between the lithosphere and the upper mantle stays constant (Funiciello et al., 2003). In nature, the average buoyancy of an oceanic plate depends on the oceanic crust and mantle lithosphere thicknesses, i.e. on the age of the oceanic floor. Oceanic lithospheres younger than $\sim 10$ Ma have positive buoyancy (Cloos, 1993). The density contrast between young oceanic lithosphere and asthenosphere, however, is modified by metamorphic changes in the subduction zone from basaltic/gabbroic crust into denser amphibolitic or eclogitic rocks (Spencer, 1987). This metamorphism reaction may shift the buoyancy of young oceanic plates from positive to negative (Cloos, 1993). In this experimental set, we consider that the average buoyancy of the subducting lithosphere does not depend on the age of the plate and that the decrease in slab pull when the ridge approaches the trench only results from the thinning of the subducting plate.

The lateral distance between the plates and the sides of the Plexiglas tank is larger than the equivalent size of advected cells within the upper mantle, in order to minimize lateral boundary effects. Thus, in our models, we assume that each lithospheric plate is completely surrounded by weakness zones (i.e. ridges or transform faults) whose viscosity is that of the surrounding mantle (see Funiciello et al., 2004 for more details). The subducting and overriding plates are decoupled by a weak layer of glucose syrup at trench, which prevents plates to stick during the experiment. In addition, the entire surface of the subducting plate is covered with a thin layer $(\sim 1 \mathrm{~mm})$ of $30 \%$ of petrolatum and $70 \%$ of paraffin oil, in order to minimize the friction at the plates interface (Duarte et al., 2013, 2014, 2015). The proportion of paraffin oil is slightly smaller than that recommended by Duarte et al. (2014) to scale the interplate friction in this kind of experiments, but the two plates being additionally separated by a glucose syrup layer further diminishes the interplate friction.

\section{Experimental results}


Five experiments have been performed (Fig. 3). We use model 1, in which the subducting plate has a constant thickness, as a reference. The other four models reproduce the subduction on an oceanic ridge parallel to the trench: model 2 does not include any overriding plate while models 3 to 5 include an overriding plate advancing toward the trench at different velocities.

For each experiment, we measure the ridge and trench velocities ( $\mathrm{Vr}$ and $\mathrm{Vt}$ respectively, see Fig. 1) every two minutes. $\mathrm{Vr}$ is noted positive when the ridge advances towards the subduction zone, while $\mathrm{Vt}$ is considered positive when the slab is rolling back (trench motion towards the oceanic plate). In all experiments, the trench-perpendicular deformation of the subducting plate is generally two orders of magnitude smaller than plates velocities (see top views of experiments in supplementary data). Then, we compute the subduction velocity Vs $\mathrm{Vr}+\mathrm{Vt}$. We also note the dip of the slab every two minutes at different depths: at a depth of 2 $\mathrm{cm}(\sim 130 \mathrm{~km}$ in nature) below the surface of the model, and in the middle of the upper mantle at a depth of $5 \mathrm{~cm}(330 \mathrm{~km}$ in nature) below the surface of the model. In models 3,4 and 5 , we also measure the horizontal distance between the trench and the point where the top of the slab is $2 \mathrm{~cm}$ beneath the surface. The depth of the top of the slab beneath volcanic arcs being $120+/-40 \mathrm{~km}$ (England and Katz, 2010), this horizontal distance would globally correspond to the distance separating the trench from the arc region in nature.

\subsection{Model 1 (reference): constant thickness - free oceanic plate}

This model consists of the subduction of an oceanic plate with constant thickness, in the absence of any overriding plate. Such experiments have already been described in several papers (e.g., Funiciello et al., 2004; Bellahsen et al., 2005; Martinod et al., 2005). During subduction initiation, slab interaction with the base of the Plexiglas tank modeling the upper/lower mantle transition results in large variations of the subduction velocity (see Fig. 4b). This transitory evolution is described in detail in Funiciello et al. (2004). Following this transitory episode, the slab rests horizontally on the bottom of the tank and subduction becomes steady: both the dip of the slab and the subduction velocity keep an almost constant value. The steady-state subduction velocity is close to $1.05 \mathrm{~cm} / \mathrm{min}$ which may correspond to $3.7 \mathrm{~cm} / \mathrm{yr}$ in nature (see Table 2), 80\% resulting from slab roll-back (Fig. 4c). The remaining $20 \%$ results from the advance of the oceanic plate towards the trench. The dip of the slab is $\sim 55^{\circ}$ at $5 \mathrm{~cm}$ beneath the surface of the model, and close to $40-45^{\circ}$ at $2 \mathrm{~cm}$-depth (Fig. $4 \mathrm{~d}$ ). All these values remain constant until the trailing edge of the plate reaches the trench and 
subducts in the upper mantle.

\subsection{Model 2: subduction of an oceanic plate with decreasing thickness}

This model is similar to model 1, except the thickness of the subducting plate that decreases after the subduction of $30 \mathrm{~cm}(\sim 2000 \mathrm{~km}$ in nature) of $12 \mathrm{~mm}$-thick $(80 \mathrm{~km}$ in nature) lithosphere. The thickness of the remaining $20 \mathrm{~cm}$-long segment of the plate linearly decreases from $12 \mathrm{~mm}$ to $3 \mathrm{~mm}$, to reproduce the decreasing thickness of a progressively younger oceanic plate (Fig. 2). The first part of model 2 is comparable to that described for model 1: subduction initiation, followed by a steady-state regime of subduction as long as the thick slab segment is subducting. During this steady-state period, both the dip of the slab ( $\sim 55^{\circ}$ at $5 \mathrm{~cm}$ depth and $40-45^{\circ} 2 \mathrm{~cm}$ below the surface) and the velocity of subduction $(\sim 1.01$ $\mathrm{cm} / \mathrm{min}$ ) are similar to those measured in model 1 (Fig. 4). When the thickness of the slab at the trench starts decreasing, the velocity of subduction slows down and the dip of the slab progressively increases. Changes in the dynamics of subduction occur slowly, and progressively accelerate after 30 minutes of experiment when $\sim 10 \mathrm{~cm}$ of thinning plate have subducted (Fig. 4). At the end of the model, when the ridge subducts, the slab is folding forward and its dip exceeds $90^{\circ}$ (Fig. 5F). The increasing dip of the slab is accompanied by a diminution of the radius of curvature of the subducting plate close to the trench (Fig. 5). The progressive decrease of the subducting plate thickness at the trench is accompanied by a decrease of the trench velocity (Vt) from $\sim 0.8 \mathrm{~cm} / \mathrm{min}$ to $\sim 0.1 \mathrm{~cm} / \mathrm{min}$ (Fig. $4 \mathrm{~b}$ ). In contrast, the trenchward velocity of the oceanic plate (Vr) increases from $\sim 0.2 \mathrm{~cm} / \mathrm{min}$ to $\sim 0.5 \mathrm{~cm} / \mathrm{min}$. This increase does not compensate the large diminution of $\mathrm{Vt}$, and the subduction velocity at the end of model is only half the steady-state velocity of subduction that prevailed during the subduction of the thick part of the plate.

\subsection{Model 3: subduction beneath a free continental plate}

The subducting plate in model 3 is identical to that in model 2. The difference between these models was a buoyant overriding plate that moves freely above the subduction zone that was added in model 3 . The free upper plate does not significantly modify the dynamics of subduction (Fig. 4). During the steady-state regime, the subduction velocity is $\sim 1.14 \mathrm{~cm} / \mathrm{min}$ (4 cm/yr in nature), close to the steady-state subduction velocity in models 1 and 2 . As in model 2 , the subduction velocity progressively decreases when the subducting plate thins 
(Fig. 4b). Trench retreat accounts for $\sim 80 \%$ of the subduction velocity during the steady-state period as in models 1 and 2 (Fig. 4c). This ratio decreases during the subduction of the thinning slab segment, and eventually reaches $\sim 50 \%$ at the end of the experiment vs. $\sim 20 \%$ in model 2. The dip of the slab increases after the slab starts thinning (Fig. 4d). However, the increase in slab dip is less marked than in model 2, the final dip of the slab at mid-mantle depth being $\sim 70^{\circ}$ in model 3 while it exceeded $90^{\circ}$ in model 2.

\subsection{Models 4 and 5: subduction beneath a trenchward advancing continental plate}

In these two models, the motion of the continental plate is imposed by a piston pushing the overriding plate toward the subducting plate. In model 4 , the continental plate is pushed at a velocity of $1.05 \mathrm{~cm} / \mathrm{min}$, close to the steady-state subduction velocity of a thick oceanic plate beneath a free continent. In model 5 , the piston velocity is $2.3 \mathrm{~cm} / \mathrm{min}$, approximately twice the steady-state subduction velocity. In these experiments, Vt (trench velocity) is close to the velocity imposed by the piston $(\mathrm{Vp})$, the difference between them corresponding to the deformation velocity of the overriding plate $\left(V_{d}\right)$ which is one order of magnitude smaller than $\mathrm{Vt}$ (Figs. 6b). The ridge velocity ( $\mathrm{Vr}$ ), which corresponds to the difference between the subduction velocity (Vs) and the trench velocity $(\mathrm{Vt})$, varies between 0.02 and $0.25 \mathrm{~cm} / \mathrm{min}$ in model 4 , and between -0.24 and $0 \mathrm{~cm} / \mathrm{min}$ in model 5 . Here, we do not observe any decrease of subduction velocity when the ridge approaches the trench, as in the previous experiments, because this velocity is largely controlled by lateral boundary conditions.

We report in Fig. $6 c$ the deep dip of the slab. It is $\sim 45^{\circ}$ during steady-state subduction in model 4 , vs. $35^{\circ}$ in model 5 . In model 4 , we do not observe any increase of the slab dip when the thinning segment of the plate is subducting. Instead, in model 5, the dip of the slab decreases below $30^{\circ}$.

We also measure the evolution of the trench-perpendicular length of the overriding plates during experiments (Fig. 6d). While the free overriding plate does not deform significantly in the previously described model 3, some gentle shortening occurs in model 4 during the initiation of subduction at rates of $\sim 5 \times 10^{-5} \mathrm{~s}^{-1}$. The corresponding shortening rate in nature would be $5 \times 10^{-17} \mathrm{~s}^{-1}$ (Table 2). During the steady-state subduction of the thick plate segment, the upper plate does not record any significant shortening. At the end of model 4 , when the ridge is approaching the subduction zone (after $23 \mathrm{~min}$ ), bulk shortening is recorded again at gentle rates of $\sim 5 \times 10^{-5} \mathrm{~s}^{-1}$. The final bulk strain is $\sim 6 \%$ in this model (Fig. 6d). In model 5, 
shortening occurs during the entire duration of the experiment. The rate is faster than model 4 with a value of $\sim 1 \times 10^{-4} \mathrm{~s}^{-1}$ on average during the subduction initiation, then a slightly lower value of $\sim 7 \times 10^{-5} \mathrm{~s}^{-1}$ during the steady-state stage, and a final increase to $\sim 1 \times 10^{-4} \mathrm{~s}^{-1}$ on average during the slab thinning phase. The final bulk strain is $13 \%$ in this model (Fig. 6d).

\section{Discussion}

\subsection{Free subduction of a trench-parallel oceanic ridge}

The evolution of model 1 is similar to the evolution of experiments described in Funiciello et al. (2004), Bellahsen et al. (2005) and Martinod et al. (2005). It corresponds to the first mode of subduction (mode 1) described by Bellahsen et al. (2005), in which subduction essentially results from slab roll-back. Following subduction initiation, the slab deposits on the bottom of the box modeling the upper/lower mantle discontinuity, and the process of subduction becomes steady-state with a constant slab dip. All the parameters describing the evolution of subduction (slab dip, subduction velocity, ratio between subduction velocity and roll-back velocity) remain constant until the end of experiment (Fig. 4).

Comparison between models 1 and 2 readily shows the effects of changes in the thickness of the subducting plate on subduction dynamics. Model 2 presents the same initial evolution than model 1 . Subduction becomes rapidly steady and remains constant until the thinner plate segment reaches the trench. Then, the subduction velocity decreases. Subduction velocity results from equilibrium between the slab pull force that drives subduction on the one hand, and resisting forces on the other hand. Resisting forces arise from the bending of the slab $(\mathrm{Rb})$, slab-mantle shear (Rs), and toroidal mantle flow induced by slab roll-back (Rt) (e.g., Funiciello et al., 2003). Materials used in these models being Newtonian, all these resisting forces depend on the subduction velocity.

Thinner slab subduction results in a diminution of the slab pull force. The density of the subducting plate being constant, the slab pull force is proportional to the volume of the slab and hence depends on the thickness of the subducting plate. Therefore, thinner slab subduction explains the decreasing subduction velocity. This effect is not visible as soon as the thinning plate segment reaches the trench. Indeed, the slab pull force only changes markedly when a significant portion of the slab is thinner. In model 2 , the diminution of subduction velocity is noticeable following 30 minutes of the experiment, i.e. 10 minutes after the arrival at trench of the thinning plate segment (Fig. 4b). At that moment, $8.7 \mathrm{~cm}$ 
(corresponding to $570 \mathrm{~km}$ in nature) of the beveled slab segment has subducted (Fig. 4a), which is almost half of the beveled plate length in this experiment, and the thickness of the slab at trench is $8 \mathrm{~mm}$ vs. $12 \mathrm{~mm}$ for the thick slab segment. But the slab pull force has only dropped by $11 \%$, which explains why the diminution of the subduction velocity is only barely noticeable at that time. Fig. 7a shows that the decreasing subduction velocity can be correlated with the decrease of the slab pull in model 2.

The diminution of the subduction velocity results from the large decrease of the roll-back velocity Vt. This velocity decrease is partly compensated by an increase of the trenchward velocity of the overriding plate ( $\mathrm{Vr}$ ). Indeed, the force $\mathrm{Rb}$ necessary to achieve slab bending depends on the thickness of the plate: it is proportional to: $\left(\eta_{0} T_{O}{ }^{3} / r^{3}\right)$, where $\eta_{0}$ is the subducting plate viscosity, $\mathrm{T}_{\mathrm{O}}$ the thickness of the plate, and $\mathrm{r}$ the radius of curvature of the slab at trench (e.g., Conrad and Hager, 1999; Schellart, 2009). Other resistive forces (Rs and $\mathrm{Rt}$ ), in contrast, do not depend on the thickness of the slab. We observe that the thinner the slab, the smaller its radius of curvature, and hence the larger the dip of the slab. Slab dip increase leads to larger trenchward velocity of the oceanic plate (Vr). With a thinner slab, it becomes easier to achieve subduction diminishing the radius of curvature of the slab and increasing its dip which, in turn, increases the trenchward plate motion $\mathrm{Vr}$, instead of pursuing slab roll-back.

The evolution of model 3 is very comparable to that of model 2, showing that a free overriding plate passively follows slab roll-back. The dip of the slab is similar in both experiments during steady-state subduction. The thinner subducting plate in model 3 also results in slab steepening and in a diminution of the subduction velocity, although these changes are smoother than in model 2 (Fig. 4). Indeed, both the superficial poloidal and toroidal mantle flow above the steepening slab are directed towards the trench (Funiciello et al., 2006), which favors the trenchward motion of the overriding plate. This motion, in turn, limits the diminution of trench retreat velocity. However, the analysis of subduction velocity vs. slab pull (Fig. 7) shows a similar evolution for models 2 and 3.

\subsection{Effects of boundary conditions on oceanic ridge subduction}

The effect of the overriding plate on the dynamics of ridge subduction is largely different depending on the adopted boundary conditions. If the upper plate is free to move (model 3), it passively follows the retreating trench and the velocity of subduction decreases when the 
ridge approaches the trench (see Section 4.1). In contrast the trenchward upper plate motion in models 4 and 5 is essentially controlled by lateral boundary conditions. The modelled trenchperpendicular dimension of the plates is moderate, at only $200 \mathrm{~mm}$ (corresponding to $\sim 1300$ $\mathrm{km}$ ) for the overriding plate. Then, the shortening velocity of the overriding plate is more than one order of magnitude smaller than the piston velocity, and the trench retreat is almost as rapid as the advance of the piston.

The deep steady-state dip of the slab is $53^{\circ}$ in model 3, vs. $45^{\circ}$ and $35^{\circ}$ in models 4 and 5 , respectively. The smaller slab dip in model 5 results from the larger piston velocity: the larger the trenchward overriding plate velocity, the smaller the dip of the slab, as already noted by several authors, both in models reproducing oceanic subduction (e.g., Heuret et al., 2007; Espurt et al., 2008; Guillaume et al., 2018) as well as in global analysis of present-day subduction zones (Lallemand et al., 2005).

When the thinner slab segment subducts, the evolution of the subducting plate geometry largely differs depending on the overriding plate velocity. It is visible comparing the deep slab dip measured in the middle of the upper mantle: in model 3, the dip of the slab increases from $53^{\circ}$ to $70^{\circ}$ while the trenchward upper plate motion slows down (Fig. 4b). In model 4, it remains approximately constant $\left(\sim 45^{\circ}\right)$ until the end of experiment (Fig. 5c). In model 5, in contrast, the dip of the slab decreases from $35^{\circ}$ to $27^{\circ}$ during slab thinning (Fig. 5c). In Fig. 8, we report the horizontal distance between the trench and the projection at the surface of the point located on top of the slab at a depth of $2 \mathrm{~cm}$. In models 3 and 4, this distance slightly decreases when the slab is thinning: from 13 to $6 \mathrm{~mm}$ (87 to $41 \mathrm{~km}$ in nature) and from 26 to $20 \mathrm{~mm}$ (165 to $127 \mathrm{~km}$ in nature) in models 3 and 4, respectively. When the radius of curvature of the slab close to the trench is smaller, the dip of the slab increases more rapidly beneath the overriding plate. In model 5, in contrast, this distance increases from 50 to 110 $\mathrm{mm}$ ( 330 to $720 \mathrm{~km}$ in nature) during bevelled plate subduction, accompanying slab flattening. Approximately $90 \%$ of this increase is achieved during the last 6 minutes of the experiment. The lateral migration velocity $(\sim 5 \mathrm{~cm} / \mathrm{min})$ would correspond to $37 \mathrm{~km} / \mathrm{Ma}$ in nature.

The diminution of the superficial slab dip in model 5 can be understood by considering the evolution of free subduction experiments (models 2 and 3): when the ridge approaches the trench, the pull of the slab is not large enough to produce the toroidal mantle flow necessary to accommodate slab retreat. On the other hand, in model 5, trench retreat is imposed by the lateral boundary conditions that force the overriding plate to move trenchward. Then, the 
trench moves rapidly towards the oceanic plate while the deep part of the slab instead is not able to move back as rapidly. This situation results in the appearance of a superficial slab segment with a very small dip which would, in nature, be marked by an increase of the distance between the trench and the volcanic arc (Figs. 8 and 9).

The upper plate shortening also depends on lateral boundary conditions applied on the overriding plate, as shown by negligible deformation in "free" model 3 contrasting with the upper plate shortening observed in models with imposed kinematic boundary conditions. In model 4, plate shortening occurs during subduction initiation and at the end of the experiment when the ridge approaches the trench. It corresponds to periods during which the imposed trenchward velocity of the plate is larger than the spontaneous trench retreat velocity in the free subduction experiments (models 2 and 3). During steady-state subduction of the thick plate, the velocity of the piston is close to the "free" trench retreat velocity, and the upper plate does not shorten. When the ridge approaches the trench, the upper plate shortening rate is on average $5 \times 10^{-5} \mathrm{~s}^{-1}$. The force per unit length applied by the piston on the overriding plate can be simply estimated considering the superficial strain rate and assuming the plate behaves as a thin plate (e.g., Chen et al., 2015). We observe that deformation is homogeneous in the overriding plate, meaning that forces arising from shear traction at the base of the plate are small compared to horizontal forces exerted by the piston and the oceanic plate. The trench perpendicular horizontal force is $F_{\text {piston }}=2(d \Sigma / d t) \eta h$, where $d \Sigma / d t$ is the strain rate, $\eta$ and $h$ are the viscosity and thickness of the upper plate, respectively. The force applied by the piston is $0.09 \mathrm{~N} / \mathrm{m}$ in model 4 during the subduction of the thinner part of the plate, which would correspond to $2.2 \times 10^{12} \mathrm{~N} / \mathrm{m}$ in nature (Table 2). The slab pull force in these experiments decreases from $1.57 \mathrm{~N} / \mathrm{m}$ during the subduction of the thick plate to $0.91 \mathrm{~N} / \mathrm{m}$ at the end of experiment, i.e. it is always more than one order of magnitude larger than the force exerted by the piston on the upper plate.

In model 5, plate shortening occurs during the entire time of the experiment as the imposed overriding plate velocity $(2.3 \mathrm{~cm} / \mathrm{min})$ is always higher than the spontaneous trench retreat velocity. The shortening rate is $\sim 7 \times 10^{-5} \mathrm{~s}^{-1}$ during the steady-state stage, and it increases to $\sim 1 \times 10^{-4} \mathrm{~s}^{-1}$ during the slab thinning phase. The force applied by the piston varies from 0.13 to $0.19 \mathrm{~N} / \mathrm{m}$ in this experiment, which is larger than in model 4 but remains largely smaller than the slab pull force. 


\subsection{Comparison with Neogene ridge subduction in Southern Patagonia} The NNW-SSE oriented Chile spreading ridge separates the Nazca and Antarctic plates. The divergence between these two plates is approximately E-W, and the plate boundary consists in ridge segments oriented $\sim \mathrm{N} 165^{\circ} \mathrm{E}$, i.e. approximately parallel to the trench in Southern Patagonia (Fig.10), separated by transform faults. The ridge segments reached the subduction zone $16 \mathrm{Ma}$ ago beneath the South American plate at $55^{\circ} \mathrm{S}$ (Cande and Leslie, 1986; Breitsprecher and Thorkelson, 2009). Plate reconstructions show that a $700 \mathrm{~km}-$ long trenchparallel ridge segment subducted beneath the South American plate between 13.5 and $12 \mathrm{Ma}$ (Fig. 10). The geometry of transform faults and ridge segments resulted in a rapid northward migration of the triple junction between the Antarctic, Nazca and South American plates. Two other shorter segments subducted beneath South America 6 and 3 Ma ago, resulting in the present-day position of the triple junction located near the Taitao peninsula at $46^{\circ} 30^{\prime} \mathrm{S}$ (Cande and Leslie, 1986; Lagabrielle et al., 2004; Guillaume et al., 2009; Ramirez de Arellano et al., 2012).

South America plate is a major lithospheric plate whose dimensions largely exceed the size of Southern Patagonia. Then, although subduction is a major engine of plate kinematics, we consider that the motion of South America was not significantly modified by the subduction of a $700 \mathrm{~km}$-long oceanic ridge beneath Southern Patagonia. Data published in Sdrolias and Muller (2006) confirm that the westward velocity of South America in the hot spot reference frame did not change significantly during the Cenozoic. Then, we consider that the set-up adopted in models 4 and 5, in which the motion of the overriding plate is not free but is instead imposed by lateral boundary conditions is particularly appropriate to study the effects of ridge subduction beneath Southern Patagonia.

\subsubsection{Migration of the magmatic arc}

An eastward migration of the magmatic arc during the early Miocene has been observed in Southern Patagonia (Michael, 1983). It resulted in the occurrence of several calco-alkaline to alkaline plutons located $\sim 150 \mathrm{~km}$ east of the Patagonian batholith which was the previous locus of magmatism (Ramirez de Arellano et al., 2012). Noticeably, those isolated plutons located in the retroarc were rapidly exhumed, and constitute important mountains ranges (Fig. 10) such as the San Lorenzo massif ( 6.5 Ma old, Welkner, 1999, 2002), Fitz Roy and Cerro Torre massif ( 17-16 Ma, Ramirez de Arellano et al. 2012). This migration of magmatism has been explained either by the development of a transient low- 
angle subduction under Patagonia that produced the eastward migration of the arc front, by subduction erosion of the continental forearc, or by a combination of the two phenomena (Espinoza et al., 2010; Ramirez de Arellano et al., 2012). According to Espinoza et al. (2010), the eastward migration of the arc is possibly associated with the arrival of the Chile Ridge and the later ridge-trench collision. Ramirez de Arellano et al. (2012) note, however, that this period also recorded particularly high convergence velocities between the Nazca subducting plate and South America. Indeed, both the angle and rate of convergence changed markedly at the Oligocene-Miocene transition. During the Oligocene, the subduction velocity was moderate $(\sim 5 \mathrm{~cm} / \mathrm{yr})$ and oblique to the trench (Pardo-Casas and Molnar, 1987; Somoza, 1998; Somoza and Ghidella, 2012). Following the rupture of the Farallon plate that occurred $23 \mathrm{Ma}$ ago (Lonsdale, 2005), the relative velocity between the Nazca plate and South America increased to $13 \mathrm{~cm} / \mathrm{yr}$ at the latitude of South Patagonia, and the azimuth of convergence became approximately perpendicular to the trench. Then, Ramirez de Arellano et al. (2012) propose that the early Miocene eastward migration of the magmatic arc may also result from subduction erosion due to the larger convergence velocity at that time.

The analogue experiments we performed mimic the behavior of a subduction zone with a trench-perpendicular convergence and an approaching trench-parallel ridge, i.e. similar to the early Miocene Patagonian situation. These models show that the dynamics of the slab before ridge subduction depends on plate-convergence velocities. If the overriding plate motion is not imposed by lateral boundary conditions (model 3) or if its trenchward motion is moderate (model 4), the dip of the slab increases and the distance between the volcanic arc and the trench should decrease. In contrast, if the continental plate is quickly moving towards the trench (model 5), the slab flattens beneath the overriding plate resulting in an increase of the distance between the trench and the volcanic arc preceding ridge subduction (Fig. 9).

Figs. 8 and 10 show that the magmatic arc in Southern Patagonia at $49^{\circ} \mathrm{S}$ started to migrate eastward $\sim 20 \mathrm{Ma}$ ago, i.e. approximately $7 \mathrm{Ma}$ before the subduction of the ridge. Close to $47.5^{\circ} \mathrm{S}$, Espinoza et al. (2010) propose that the eastward migration of the magmatic arc initiated more than $10 \mathrm{Ma}$ ago, before the 6 Ma-old subduction of the ridge. The ridge segment that subducted beneath this part of Patagonia, however, was short, and it is possible that the geometry of the slab at this latitude was modified by the long ridge segment that previously subducted south of this region.

South-America has been moving westward in the hot-spot reference frame since the separation from Africa and the opening of the Southern Atlantic Ocean (e.g., Silver et al., 
1998) during Late Cretaceous times (Torsvik et al., 2009; Heine et al., 2013), triggering initiation of Andean deformation along the Southern Patagonian Andes (Ghiglione et al., 2014, 2015). Models suggest that this westward motion explains the gentle dip of slabs beneath South America, and the Cenozoic appearance of horizontal slab segments beneath the Central Andes (e.g., Husson et al., 2008; Espurt et al., 2008; Martinod et al., 2010; Schepers et al., 2017). The Miocene evolution of the Southern Patagonia may thus correspond to model 5 , in which the ridge is subducting beneath an overriding plate that moves rapidly towards the trench. Models do not exclude the possibility that part of the magmatic arc migration resulted from subduction erosion. They show, however, that some Miocene migration of the magmatic arc, and eventually the total amount of arc migration may have resulted from slab flattening when the ridge was approaching the trench, as proposed by Espinoza et al. (2010). Moreover, note that these models do not take into account the possible positive buoyancy of the young subducting plate, which should furthermore favor slab flattening and arc migration towards the inner part of the continent (Espurt et al., 2008).

\subsubsection{Continental shortening}

The early Miocene has also been marked by a major episode of shortening in the Southern Patagonian Andes. Close to $51^{\circ} \mathrm{S}$, Fosdick et al. (2011) note a resumption of shortening resulting in the migration of thrusting towards the Magallanes retroarc foreland basin. Rio Rincon and Rio Castillo thrusting occurred in the Late Oligocene-Lower Miocene after 27 Ma, which approximately coincides with the rupture of the Farallón Plate, and a final episode of continental shortening occurred between 21 and $18 \mathrm{Ma}$, prior to the subduction of the ridge beneath South America. In contrast, Fosdick et al. (2011) note that tectonic shortening following $18 \mathrm{Ma}$ has been very small.

A similar evolution is reported by Ramos (1989), Coutand et al. (1999), Scalabrino et al. (2009) and Guillaume et al. (2009) at latitudes varying between 49 and $47^{\circ} \mathrm{S}$. These authors note an early Miocene episode of tectonic shortening. Deformed series are covered by upper Miocene basalts that emplaced following the subduction of the ridge. Basalts are gently inclined towards the East, but they are not affected by thrust faults. This geometry evidences long-wavelength uplift of the Southern Patagonian Andes and of its retroarc foreland basin. Middle Miocene regional uplift and foreland exhumation is also observed by Fosdick et al. (2011). Guillaume et al. (2009) propose this uplift to be the dynamic response of the South 
American lithosphere to ridge subduction, which explains why it affects both the Andean range and its foreland and why it is not accompanied by tectonic shortening.

Many parameters probably interacted and resulted in the early Miocene episode of shortening that occurred in Southern Patagonia. Experiments show that the shortening of the overriding plate is favored by the trenchward motion of the continent (model 3 vs. models 4 and 5) (see also e.g., Sobolev and Babeyko, 2005; Guillaume et al., 2018). The fast convergence that occurred between the Nazca and South American plate at that time also favored continental shortening (e.g., Pardo-Casas and Molnar, 1987). We observe that shortening periods in our experiments occur when the imposed trenchward velocity of the overriding plate is larger than the spontaneous trench retreat velocity. The trench retreat velocity of a free subducting plate is smaller when the trench approaches the ridge (see model 2). Then, it explains the increasing shortening velocity of the upper plate when the ridge approaches the trench observed in models 4 and 5. Therefore, models suggest that the early Miocene episode of shortening observed in the Southern Patagonian Andes may also partly result from the ridge approaching the trench, and that the end of shortening in Southern Patagonia coincides with ridge subduction.

\section{Conclusions}

Subduction of an increasingly thinner plate simulating the arrival of an oceanic spreading ridge at the trench results in a change of the force balance within the subduction system. Slab roll-back velocity decreases because the slab pull cannot anymore maintain the toroidal mantle flow. If the convergence velocity is not imposed by lateral boundary conditions, the thinner the slab, the smaller its radius of curvature, and the larger the dip of the slab. In contrast, if the overriding plate motion is controlled by far-field boundary conditions and if it moves rapidly trenchward, then the superficial dip of the slab decreases. It results in an increase of the distance between the trench and the volcanic arc prior to ridge subduction. Models then suggest that the Miocene eastward migration of the magmatic arc that occurred in the Southern Patagonian region a few Myrs before the arrival at trench of the Chile Ridge may have resulted from the combination of a relatively fast westward motion of the South American plate over an increasingly younger and thinner Nazca plate. 
Acknowledgments: Authors thank INSU-CNRS (Institut National des Sciences de l'Univers - Centre National de la Recherche Scientifique, France) (Syster program), the ECOS-Sud program (A15-U02 project), and the University of Bourgogne-Franche-Comté for financial support. Analogue models were realized in the Laboratory of Analogue Modelling of the University of Rennes. We acknowledge Philippe Goncalves for advices and discussions, and Edwin Baynes for his help in polishing the manuscript. We would also like to thank the reviewers David Boutelier and Joao Duarte for their insightful and constructive comments.

\section{References}

Arrial, P.A., Billen, M.I., 2013. Influence of geometry and eclogitization on oceanic plateau subduction. Earth and Planetary Science Letters, 363, 34-43.

Bellahsen, N., Faccenna, C., Funiciello, F., 2005. Dynamics of subduction and plate motion in laboratory experiments: insights into the "plate tectonics" behavior of the Earth. Journal of Geophysical Research: Solid Earth, 110(B1).

Breitsprecher, K., Thorkelson, D.J., 2009. Neogene kinematic history of Nazca-AntarcticPhoenix slab windows beneath Patagonia and the Antarctic Peninsula. Tectonophysics, 464(1), 10-20.

Cande, S.C., Leslie, R.B., 1986. Late Cenozoic tectonics of the southern Chile trench. Journal of Geophysical Research: Solid Earth, 91(B1), 471-496.

Chen, Z., Schellart, W.P., Duarte, J.C., 2015. Quantifying the energy dissipation of overriding plate deformation in three-dimensional subduction models. Journal of Geophysical Research Solid Earth 120, 519-536.

Chung, W.Y., Kanamori, H., 1978. Subduction process of a fracture zone and aseismic ridges - the focal mechanism and source characteristics of the New Hebrides earthquake of 1969 January 19 and some related events. Geophysical Journal International, 54(1), 221-240.

Cloos, M., 1993. Lithospheric buoyancy and collisional orogenesis: Subduction of oceanic plateaus, continental margins, island arcs, spreading ridges, and seamounts. Geological Society of America Bulletin, 105(6), 715-737. 
Conrad, C.P., Hager, B.H., 1999. Effects of plate bending and fault strength at subduction zones on plate dynamics. Journal of Geophysical Research: Solid Earth, 104(B8), 1755117571.

Conrad, C.P., Lithgow-Bertelloni, C., 2007. Faster seafloor spreading and lithosphere production during the mid-Cenozoic. Geology, 35(1), 29-32.

Coutand, I., Diraison, M., Cobbold, P.R., Gapais, D., Rossello, E.A., Miller, M., 1999. Structure and kinematics of a foothills transect, Lago Viedma, southern Andes (49 $\left.30^{\prime} \mathrm{S}\right)$ : Journal of South American Earth Sciences, v. 12, p. 1-15.

Duarte, J. C., Schellart, W. P., Cruden, A. R., 2013. Three-dimensional dynamic laboratory models of subduction with an overriding plate and variable interplate rheology. Geophysical Journal International, 195(1), 47-66.

Duarte, J. C., Schellart, W. P., Cruden, A. R., 2014. Rheology of petrolatum-paraffin oil mixtures: applications to analogue modelling of geological processes. Journal of Structural Geology, 63, 1-11.

Duarte, J. C., Schellart, W. P., Cruden, A. R., 2015. How weak is the subduction zone interface? Geophysical Research Letters, 42(8), 2664-2673.

England, P.C., Katz, R.F., 2010. Melting above the anhydrous solidus controls the location of volcanic arcs. Nature, 467(7316), 700-703.

Espinoza, F., Morata, D., Polve, M., Lagabrielle, Y., Maury, R.C., Rupelle, A.D.L., Suarez, M., 2010. Middle Miocene calc-alkaline volcanism in Central Patagonia (47 S): petrogenesis and implications for slab dynamics. Andean Geology, 37(2).

Espurt, N., Funiciello, F., Martinod, J., Guillaume, B., Regard, V., Faccenna, C., Brusset, S., 2008. Flat subduction dynamics and deformation of the South American plate: Insights from analog modeling. Tectonics, 27(3).

Fosdick, J.C., Romans, B.W., Fildani, A., Bernhardt, A., Calderón, M., Graham, S.A., 2011. Kinematic evolution of the Patagonian retroarc fold-and-thrust belt and Magallanes foreland basin, Chile and Argentina, 51 30' S. Geological Society of America Bulletin, 123(9-10), 1679-1698.

Funiciello, F., Faccenna, C., Giardini, D., Regenauer-Lieb, K., 2003. Dynamics of retreating slabs: 2. Insights from three-dimensional laboratory experiments. Journal of Geophysical Research: Solid Earth, 108(B4). 
Funiciello, F., Faccenna, C., Giardini, D., 2004. Role of lateral mantle flow in the evolution of subduction systems: insights from laboratory experiments. Geophysical Journal International, 157(3), 1393-1406.

Funiciello, F., Moroni, M., Piromallo, C., Faccenna, C., Cenedese, A., Bui H.A., 2006. Mapping mantle flow during retreating subduction : Laboratory models analysed by feature tracking. Journal of Geophysical Research: Solid Earth, 111 (B03402).

Geist, E.L., Fisher, M.A., Scholl, D.W., 1993. Large-scale deformation associated with ridge subduction. Geophysical Journal International, 115(2), 344-366.

Ghiglione, M.C., Likerman, J., Barberón, V., Giambiagi, L., Aguirre-Urreta, M.B., Suarez, F., 2014. Geodynamic context for the deposition of coarse-grained deep-water axial channel systems in the Patagonian Andes. Basin Research 26, 726-745.

Ghiglione, M.C., Naipauer, M., Sue, C., Barberón, V., Valencia, V., Aguirre-Urreta, B., Ramos, V.A., 2015. U-Pb zircon ages from the northern Austral basin Patagonia. Cretaceous Research, 55:116-128.

Gorring, M.L., Kay, S.M., Zeitler, P.K., Ramos, V.A., Rubiolo, D., Fernandez, M.I., Panza, J.L., 1997. Neogene Patagonian plateau lavas: continental magmas associated with ridge collision at the Chile Triple Junction. Tectonics, 16(1), 1-17.

Guillaume, B., Martinod, J., Husson, L., Roddaz, M., Riquelme, R., 2009. Neogene uplift of central eastern Patagonia: Dynamic response to active spreading ridge subduction? Tectonics, 28(2).

Guillaume, B., Hertgen, S., Martinod, J., Cerpa, N., 2018. Slab dip, surface tectonics: How and when do they change following an acceleration/slow down of the overriding plate? Tectonophysics, 726, 110-120.

Heine, C., Zoethout, J., Müller, R.D., 2013. Kinematics of the South Atlantic rift.

Hervé, F., Pankhurst, R.J., Fanning, C.M., Calderón, M., Yaxley, G.M., 2007. The South Patagonian batholith: 150 my of granite magmatism on a plate margin. Lithos, 97(3), 373394.

Heuret, A., Funiciello, F., Faccenna, C., Lallemand, S., 2007. Plate kinematics, slab shape and back-arc stress: A comparison between laboratory models and current subduction zones. Earth and Planetary Science Letters, 256(3), 473-483. 
Husson, L., Conrad, C.P., Faccenna, C., 2008. Tethyan closure, Andean orogeny, and westward drift of the Pacific Basin. Earth and Planetary Science Letters, 271(1), 303-310.

Lagabrielle, Y., Suárez, M., Rossello, E.A., Hérail, G., Martinod, J., Régnier, M., De la Cruz, R., 2004. Neogene to Quaternary tectonic evolution of the Patagonian Andes at the latitude of the Chile Triple Junction. Tectonophysics, 385(1), 211-241.

Lallemand, S., Heuret, A., Boutelier, D., 2005. On the relationships between slab dip, backarc stress, upper plate absolute motion, and crustal nature in subduction zones. Geochemistry, Geophysics, Geosystems, 6(9).

Lonsdale, P., 2005. Creation of the Cocos and Nazca plates by fission of the Farallon plate. Tectonophysics, 404(3), 237-264.

Martinod, J., Funiciello, F., Faccenna, C., Labanieh, S., Regard, V., 2005. Dynamical effects of subducting ridges: insights from 3-D laboratory models. Geophysical Journal International, 163(3), 1137-1150.

Martinod, J., Husson, L., Roperch, P., Guillaume, B., Espurt, N., 2010. Horizontal subduction zones, convergence velocity and the building of the Andes. Earth and Planetary Science Letters, 299(3), 299-309.

Martinod, J., Guillaume, B., Espurt, N., Faccenna, C., Funiciello, F., Regard, V., 2013. Effect of aseismic ridge subduction on slab geometry and overriding plate deformation: Insights from analogue modeling. Tectonophysics, 588, 39-55.

Mason, W.G., Moresi, L., Betts, P.G., Miller, M.S., 2010. Three-dimensional numerical models of the influence of a buoyant oceanic plateau on subduction zones. Tectonophysics, 483(1), 71-79.

Michael, P.J., 1983. Emplacement and differentiation of Miocene plutons in the foothills of the southernmost Andes. Doctoral dissertation, Columbia University.

Pankhurst, R.J., Weaver, S.D., Hervé, F., Larrondo, P., 1999. Mesozoic-Cenozoic evolution of the North Patagonian batholith in Aysen, southern Chile. Journal of the Geological Society, 156(4), 673-694.

Pardo-Casas, F., Molnar, P., 1987. Relative motion of the Nazca (Farallón) and South American plates since Late Cretaceous time. Tectonics, 6(3), 233-248. 
Ramírez de Arellano, C., Putlitz, B., Müntener, O., Ovtcharova, M., 2012. High precision $\mathrm{U} / \mathrm{Pb}$ zircon dating of the Chaltén Plutonic Complex (Cerro Fitz Roy, Patagonia) and its relationship to arc migration in the southernmost Andes. Tectonics, 31(4).

Ramos, V.A., 1989. Andean Foothills Structures in Northern Magallanes Basin, Argentina: American Association of Petroleum Geologists Bulletin, v. 73(7), p. 887-903.

Rowan, C.J., Rowley, D.B., 2014. Spreading behavior of the Pacific-Farallón ridge system since 83 Ma. Geophysical Journal International, 197(3), 1273-1283.

Scalabrino, B., Ritz, J.F., Lagabrielle, Y., 2009. Using glacial morphology to constrain the impact of the Chile active spreading ridge subduction in Central Patagonia. In EGU General Assembly Conference Abstracts (Vol. 11, p. 8518).

Schellart, W. P., 2009. Evolution of the slab bending radius and the bending dissipation in three-dimensional subduction models with a variable slab to upper mantle viscosity ratio. Earth and Planetary Science Letters, 288(1-2), 309-319.Schepers, G., van Hinsbergen, D.J., Spakman, W., Kosters, M.E., Boschman, L.M., McQuarrie, N., 2017. South-American plate advance and forced Andean trench retreat as drivers for transient flat subduction episodes. Nature Communications, 8.

Silver, P.G., Russo, R.M., Lithgow-Bertelloni, C., 1998. Coupling of South American and African plate motion and plate deformation. Science, 279(5347), 60-63.

Sobolev, S.V., Babeyko, A.Y., 2005. What drives orogeny in the Andes?. Geology, 33(8), 617-620.

Somoza, R., 1998. Updated Nazca (Farallon)-South America relative motions during the last 40 My: implications for mountain building in the central Andean region. Journal of South American Earth Sciences, 11(3), 211-215.

Somoza, R., Ghidella, M.E., 2012. Late Cretaceous to recent plate motions in western South America revisited. Earth and Planetary Science Letters, 331, 152-163.

Spence, W., 1987. Slab pull and the seismotectonics of subducting lithosphere. Reviews of Geophysics, 25(1), 55-69.

Stern, C.R., Kilian, R., 1996. Role of the subducted slab, mantle wedge and continental crust in the generation of adakites from the Andean Austral Volcanic Zone. Contributions to mineralogy and petrology, 123(3), 263-281. 
Sdrolias, M., Müller, R.D., 2006. Controls on back-arc basin formation. Geochemistry, Geophysics, Geosystems, 7(4).

Torsvik, T.H., Rousse, S., Labails, C., Smethurst, M.A., 2009. A new scheme for the opening of the South Atlantic Ocean and the dissection of an Aptian salt basin. Geophysical Journal International, 177(3), 1315-1333.

Van Hunen, J., Van den Berg, A.P., Vlaar, N.J., 2004. Various mechanisms to induce presentday shallow flat subduction and implications for the younger Earth: a numerical parameter study. Physics of the Earth and Planetary Interiors, 146(1), 179-194.

Welkner, D., 1999. Geología del área del cerro San Lorenzo: Cordillera Patagónica Oriental, XI Región de Aysén, Chile (47 25'-47 50'S). Memoria de Título (Inédito), Universidad de Chile, Departamento de Geología.

Fig. 1. a) Schematic sketch of an experiment in which the trenchward overriding plate motion is imposed by a piston moving at a constant speed. b) Scaled top views and c) lateral views of the experimental set up. Silicone plates initially float above a layer of glucose syrup modeling the upper mantle. Oceanic and continental silicone plates have different densities $(\rho \circ, \rho c)$ and viscosities $(\eta \circ, \eta c)$. See Table 1 for more details. The thickness of the oceanic plate decreases toward the left to reproduce the age-dependence thickness of oceanic lithosphere, the left boundary of the plate representing the oceanic ridge that will be subducted during the experiment. (1 column)

Fig. 2. Thickness of the oceanic lithosphere vs. distance from the ridge in experiments (solid line) and in nature (dotted line), calculated following Cloos (1993) for a ridge accommodating $76 \mathrm{~mm} / \mathrm{yr}$ of plates divergence. (1 column)

Fig. 3. Scaled top view of the different subduction set-up used in this study. White areas correspond to the upper mantle, light brown areas to the overriding plate and dark brown areas to oceanic lithosphere. The following models are: (1) Subduction of an oceanic plate 
with constant thickness (reference model); (2) Subduction of an oceanic plate with decreasing thickness; (3) Subduction of an oceanic plate with decreasing thickness beneath a free continental plate; (4) and (5) Subduction of an oceanic plate with decreasing thickness beneath a continental plate whose trenchward motion is imposed by a piston. See Table 1 for details. ( 2 column)

Fig. 4. Time evolution of models 1, 2 and 3. a) Trench displacement (Lt) in blue, ridge displacement $(\mathrm{Lr})$ in red and amount of subduction (Ls) in orange: $\mathrm{Ls}=\mathrm{Lr}+\mathrm{Lt}$. b) Trench velocity $(\mathrm{Vt})$ in blue, ridge velocity $(\mathrm{Vr})$ in red and subduction velocity (Vs) in orange: $\mathrm{Vs}=$ $\mathrm{Vr}+\mathrm{Vt}$. c) Ratio of roll back velocity with respect to subduction velocity Vt/Vs. d) Dip of the slab measured in the middle of the upper mantle (deep dip, dashed line) and $2 \mathrm{~cm}$ below the surface (shallow dip, solid line). The error on dip measurement is $\pm 2^{\circ}$. The different experimental stages are: (A) initiation of subduction; (B) the subducting plate touches the bottom of the box; (C) steady-state subduction; (D) initiation of subducting plate thickness decrease; (E) subduction of a progressively thinner plate; $(F)$ ridge subduction. (2 column)

Fig. 5. Successive lateral views of model 2. The thinning part of the subducting plate is highlighted in orange. The red dotted line $(\mathrm{T})$ represents the bottom of the box simulating the $660 \mathrm{~km}$ depth discontinuity in nature. The different stages of the experiment are those reported on Fig. 4: (A) Initiation of subduction; (B) the slab touches the bottom of the box; (C) steady-state subduction; (D) the thinning plate reaches the trench; (E) subduction of the thinning plate, the radius of curvature of the slab at trench decreases and the dip of the slab increases; (F) ridge subduction. Slab dip is measured both at $2 \mathrm{~cm}$-depth (in white) and at 5 cm-depth (in yellow). ( 2 column)

Fig. 6. Time evolution of models 4 and 5. a) Trench displacement (Lt) in blue, ridge displacement (Lr) in red and amount of subduction (Ls) in orange: $\mathrm{Ls}=\mathrm{Lr}+\mathrm{Lt}$. b) Trench velocity $(\mathrm{Vt})$ in blue, ridge velocity $(\mathrm{Vr})$ in red, subduction velocity $(\mathrm{Vs})$ in orange: $\mathrm{Vs}=\mathrm{Vr}+$ $\mathrm{Vt}$, and shortening velocity $(\mathrm{Vd})$ in green: $\mathrm{Vd}=\mathrm{Vp}-\mathrm{Vt}$. The piston velocity $\mathrm{Vp}$ is: 1,05 $\mathrm{cm} / \mathrm{min}$ and 2,3 cm/min in models 4 and 5, respectively.c) Deep (dashed line) and shallow (solid line) slab dip. The error on dip measurement is $\pm 2^{\circ}$. d) Trench-perpendicular shortening 
of the overriding plate. The error bar on deformation measurement is $\pm 1 \mathrm{~mm}$, which corresponds here to $\pm 0.5 \%$. The different experimental stages (A-F) are similar to those reported in Fig. 4. ( 2 column)

Fig. 7. a) Subduction velocity and slab pull vs. time in model 2. The different stages (A-F) are those reported in Fig 4. b) Subduction velocity and slab pull vs. time in model 3. c) Subduction velocity vs. slab pull in models 2 and 3 . ( 2 column)

Fig. 8. Horizontal distance between the trench and the point for which the upper part of the slab is $2 \mathrm{~cm}$ beneath the surface of experiment in models 3,4 and 5. This distance approximately corresponds to the distance between the trench and the magmatic arc. Red arrows mark the beginning of the subduction of the thinning plate. For comparison, we report the time evolution before ridge subduction of the distance between the trench and the volcanic arc in Southern Patagonia at $47.5^{\circ} \mathrm{S}$ (Espinoza et al., 2010; green area) and at $49^{\circ} \mathrm{S}$ (Ramirez de Arellano et al., 2012; orange curve). (2 column)

Fig. 9. Successive interpreted lateral views of model 5. The thinning part of the subducting plate is highlighted in orange. The different stages (A-F) are those reported in Fig. 6. The distance between the volcanic arc (red triangle) and the trench (blue arrow) is indicated with scaled values. Point A is located at the surface of the slab at $2-\mathrm{cm}$ depth (130 km in nature). (1 column)

Fig. 10. Simplified geological map of Southern Patagonia showing the location and age of the Miocene magmatic arc (after Espinoza et al., 2010; Ramirez de Arellano et al., 2012). The present-day location of the South Chile Ridge (SCR) is indicated in black, and the red star indicates the present-day position of the Chile Triple Junction (CTJ), west of the Taitao Peninsula. Red to yellow lines represent past locations of the Chile Ridge segments with respect to South America at $6 \mathrm{Ma}, 10 \mathrm{Ma}, 14 \mathrm{Ma}$ and $18 \mathrm{Ma}$, respectively. Dark green area along the western border of the continent indicates the position of the Southern Patagonian Batholith (Pankhurst et al., 1999; Hervé et al., 2007). Light green areas in the central and eastern part of the South American continent correspond to the Neogene Patagonian plateau 
basalts, with ages ranging from 12 to $7 \mathrm{Ma}$ in the western part of the back-arc and from 5 to 2 Ma farther to the northeast (Gorring et al., 1997). Dashed lines on the continent show the Miocene eastward migration of the magmatic arc (after Espinoza et al., 2010 and Ramirez de Arellano et al., 2012). Small white circles correspond to Jurassic to Paleogene batholith intrusives. Black triangles are calc-alkaline Miocene plutons (see references in Espinoza et al., 2010 and Ramirez de Arellano et al., 2012). White triangles are the Quaternary volcanoes (Stern and Kilian, 1996). (2 column)

Table 1. Experimental parameters. Lengths are measured in the direction perpendicular to the trench and widths in the direction parallel to the trench. The length ( $\mathrm{Lm}$ ) and the width (Wm) of the box are $1000 \mathrm{~mm}$. The thickness of the upper mantle (Tm) is $100 \mathrm{~mm}$ which corresponds to $660 \mathrm{~km}$ in nature. The length of the oceanic plate $(\mathrm{Lo}=\mathrm{Lb}+\mathrm{Li})$ is $500 \mathrm{~mm}$. The length of the thinning part of the oceanic plate $(\mathrm{Lb})$ is $200 \mathrm{~mm}$ and the length of the part with constant thickness (Li) is $300 \mathrm{~mm}$. The thickness of the subducting plate varies gradually from a maximum of $12 \mathrm{~mm}\left(\mathrm{To}_{\max }\right)$ in the part of the subducting plate with constant thickness to a minimum of $3 \mathrm{~mm}\left(\mathrm{To}_{\mathrm{min}}\right)$. The width of both plates is $300 \mathrm{~mm}$. The length of the overriding plate (Lc) is $200 \mathrm{~mm}$ and its thickness (Tc) is $9 \mathrm{~mm}$. See also Fig. 1. (2 column)

\begin{tabular}{|c|c|c|c|c|c|c|c|}
\hline \multicolumn{2}{|c|}{ Experiment number } & ) Units & 1 & 2 & 3 & 4 & 5 \\
\hline Oceanic plate & 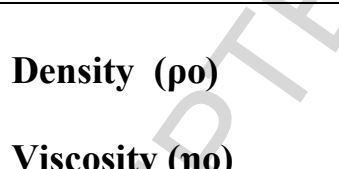 & $\begin{array}{l}\text { kg.m- } \\
3 \\
\text { Pa.s }\end{array}$ & $\begin{array}{c}1508 \\
14000 \\
0\end{array}$ & $\begin{array}{c}1507 \\
14000 \\
0\end{array}$ & $\begin{array}{c}1507 \\
14000 \\
0\end{array}$ & $\begin{array}{c}1505 \\
14000 \\
0\end{array}$ & $\begin{array}{c}1511 \\
14000 \\
0\end{array}$ \\
\hline $\begin{array}{l}\text { Continental } \\
\text { plate }\end{array}$ & 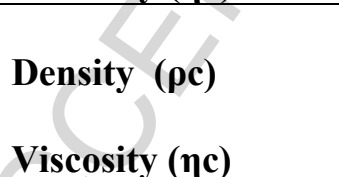 & $\begin{array}{l}\text { kg.m- } \\
3 \\
\text { Pa.s }\end{array}$ & - & $\begin{array}{l}- \\
-\end{array}$ & $\begin{array}{c}1316 \\
11500 \\
0\end{array}$ & $\begin{array}{c}1330 \\
11500 \\
0\end{array}$ & $\begin{array}{c}1326 \\
11500 \\
0\end{array}$ \\
\hline \multirow[t]{5}{*}{ Upper mantle } & 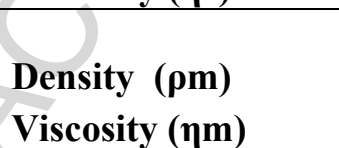 & $\begin{array}{l}\text { kg.m- } \\
3 \\
\text { Pa.s }\end{array}$ & $\begin{array}{l}1417 \\
83.1\end{array}$ & $\begin{array}{l}1417 \\
86.5\end{array}$ & $\begin{array}{l}1416 \\
83.1\end{array}$ & $\begin{array}{l}1415 \\
72.9\end{array}$ & $\begin{array}{l}1417 \\
74.8\end{array}$ \\
\hline & 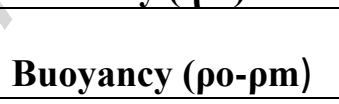 & $\begin{array}{l}\text { kg.m- } \\
3\end{array}$ & 91 & 90 & 91 & 90 & 94 \\
\hline & Piston velocity (Vp) & $\begin{array}{l}\mathrm{cm} / \mathrm{mi} \\
n\end{array}$ & - & - & - & 1.05 & 2.3 \\
\hline & $\begin{array}{l}\text { Glucose syrup } \\
\text { temperature }\end{array}$ & ${ }^{\circ} \mathrm{C}$ & 17.4 & 17.1 & 17.4 & 18.4 & 17.7 \\
\hline & Room temperature & ${ }^{\circ} \mathrm{C}$ & 17.7 & 17.9 & 18 & 19 & 18.6 \\
\hline
\end{tabular}


Table 2. Scaling parameters and ratios for the reference experiment (model 1). (2 column)

\begin{tabular}{|c|c|c|c|}
\hline & Model 1 & Nature & Ratio \\
\hline L (Length) & $0.1 \mathrm{~m}$ & $660 \mathrm{~km}$ & $L^{*}=1.5 \times 10^{-1}$ \\
\hline$\Delta \rho$ (Buoyancy) & $91 \mathrm{~kg} \cdot \mathrm{m}^{-3}$ & $50 \mathrm{~kg} \cdot \mathrm{m}^{-3}$ & $\Delta \rho^{*}=1.82$ \\
\hline g (Gravity) & $9.81 \mathrm{~m} \cdot \mathrm{s}^{-2}$ & $9.81 \mathrm{~m} . \mathrm{s}^{-2}$ & $g^{*}=1$ \\
\hline$\eta$ (Viscosity) & 83 Pa.s & $3 \times 10^{20}$ Pa.s & $\eta^{*}=2.8 \times 10^{-19}$ \\
\hline $\mathrm{t}($ Time $)$ & $1 \mathrm{~min}$ & $1.9 \mathrm{Myr}$ & $t^{*}=\eta^{*} / \Delta \rho^{*} \cdot g^{*} \cdot L^{*}=10^{-12}$ \\
\hline U (Velocity) & $1 \mathrm{~cm} / \mathrm{min}$ & $3.5 \mathrm{~cm} / \mathrm{yr}$ & $U^{*}=\Delta \rho^{*} \cdot g^{*} \cdot L^{* 2} / \eta^{*}=1.5 \times 10^{5}$ \\
\hline $\mathrm{d} \varepsilon / \mathrm{dt}$ (Strain rate) & $5 \times 10^{-5} \mathrm{~s}^{-1}$ & $5 \times 10^{-17} \mathrm{~s}^{-1}$ & $(\mathrm{~d} \varepsilon / \mathrm{dt})^{*}=\Delta \rho^{*} \cdot g^{*} \cdot \mathrm{L}^{*} / \eta^{*}=10^{12}$ \\
\hline $\begin{array}{l}F \text { (Force per unit } \\
\text { length) }\end{array}$ & $1 \mathrm{~N} / \mathrm{m}$ & $2.4 \times 10^{13} \mathrm{~N} / \mathrm{m}$ & $F^{*}=\Delta \rho^{*} \cdot g^{*} \cdot L^{* 2}=4.2 \times 10^{-14}$ \\
\hline
\end{tabular}


a)

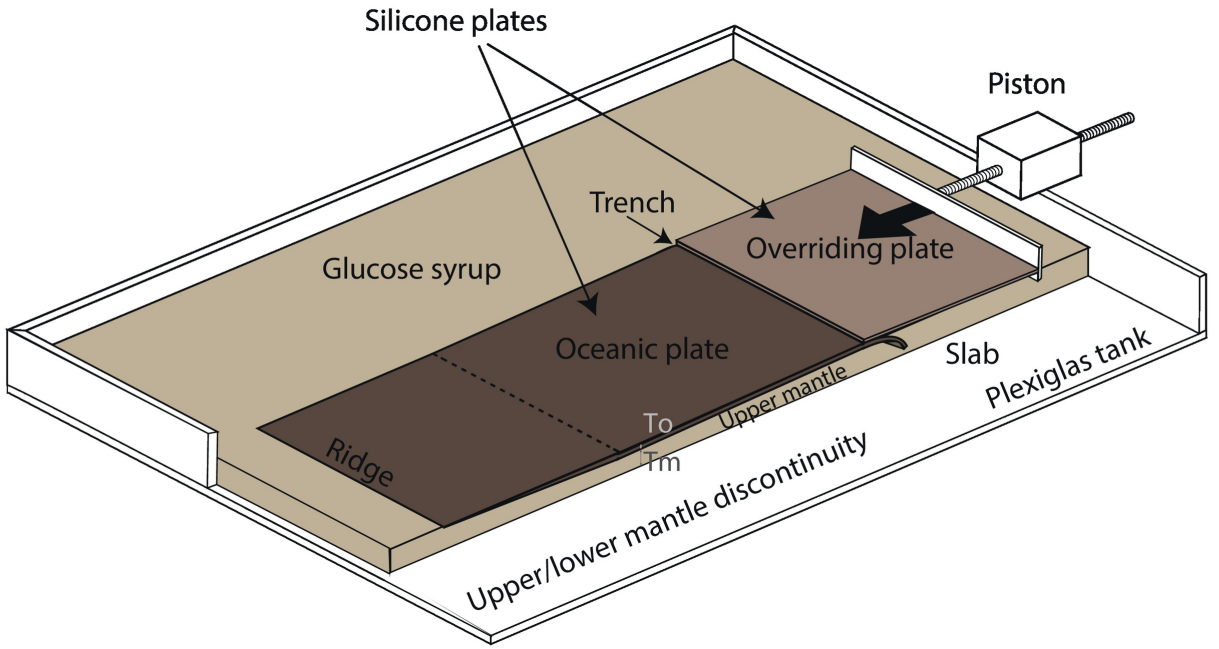

b)

Boundary of the Plexiglas tank

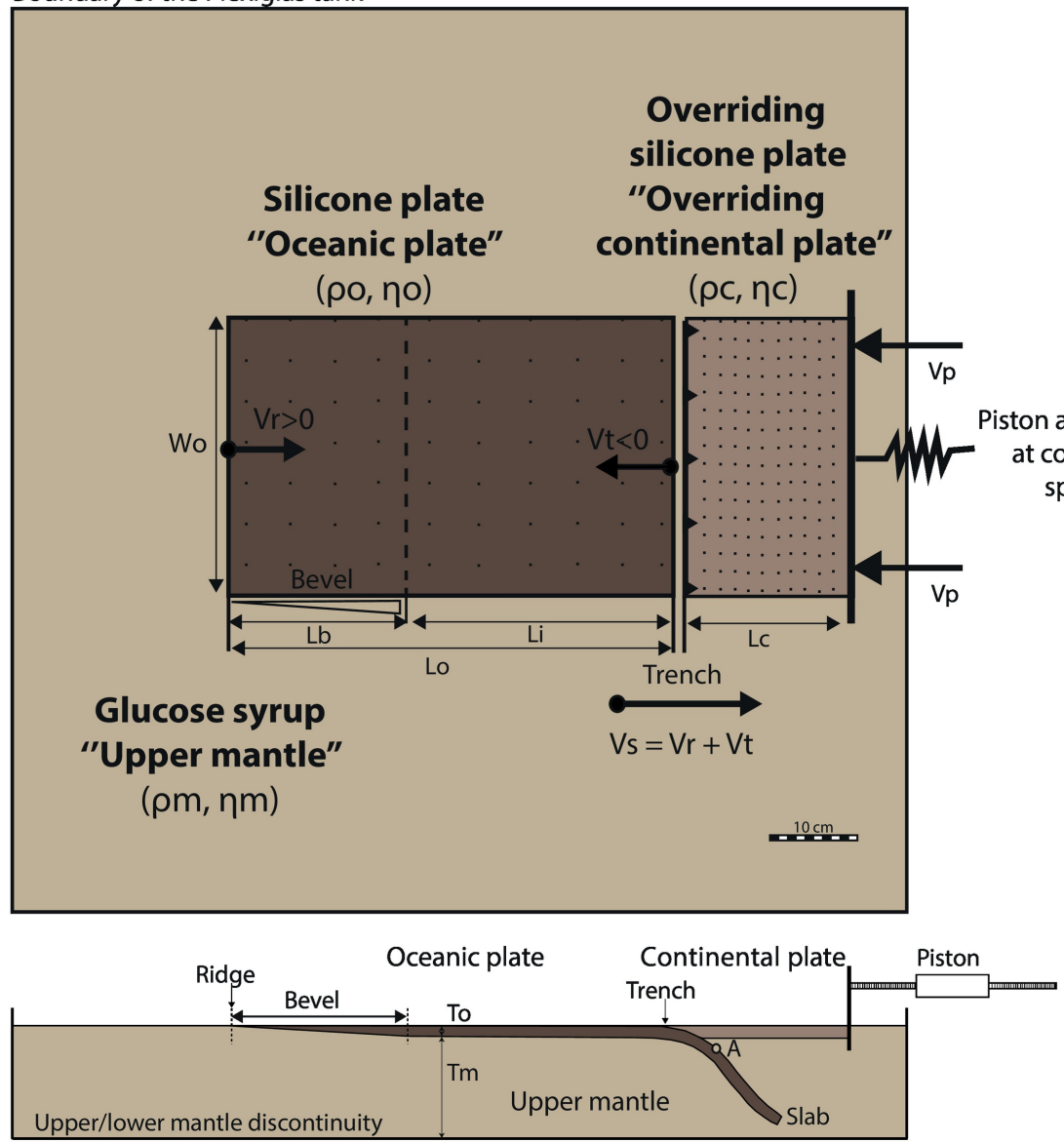

Figure 1 


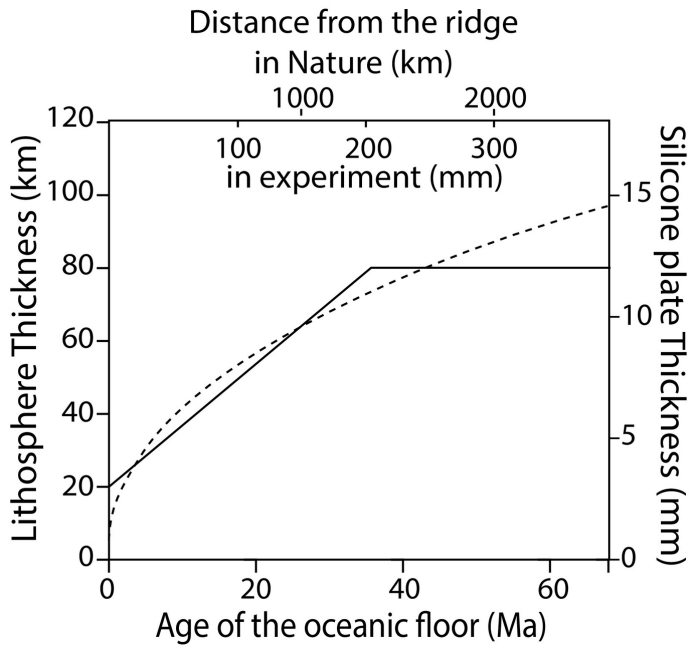

Figure 2 

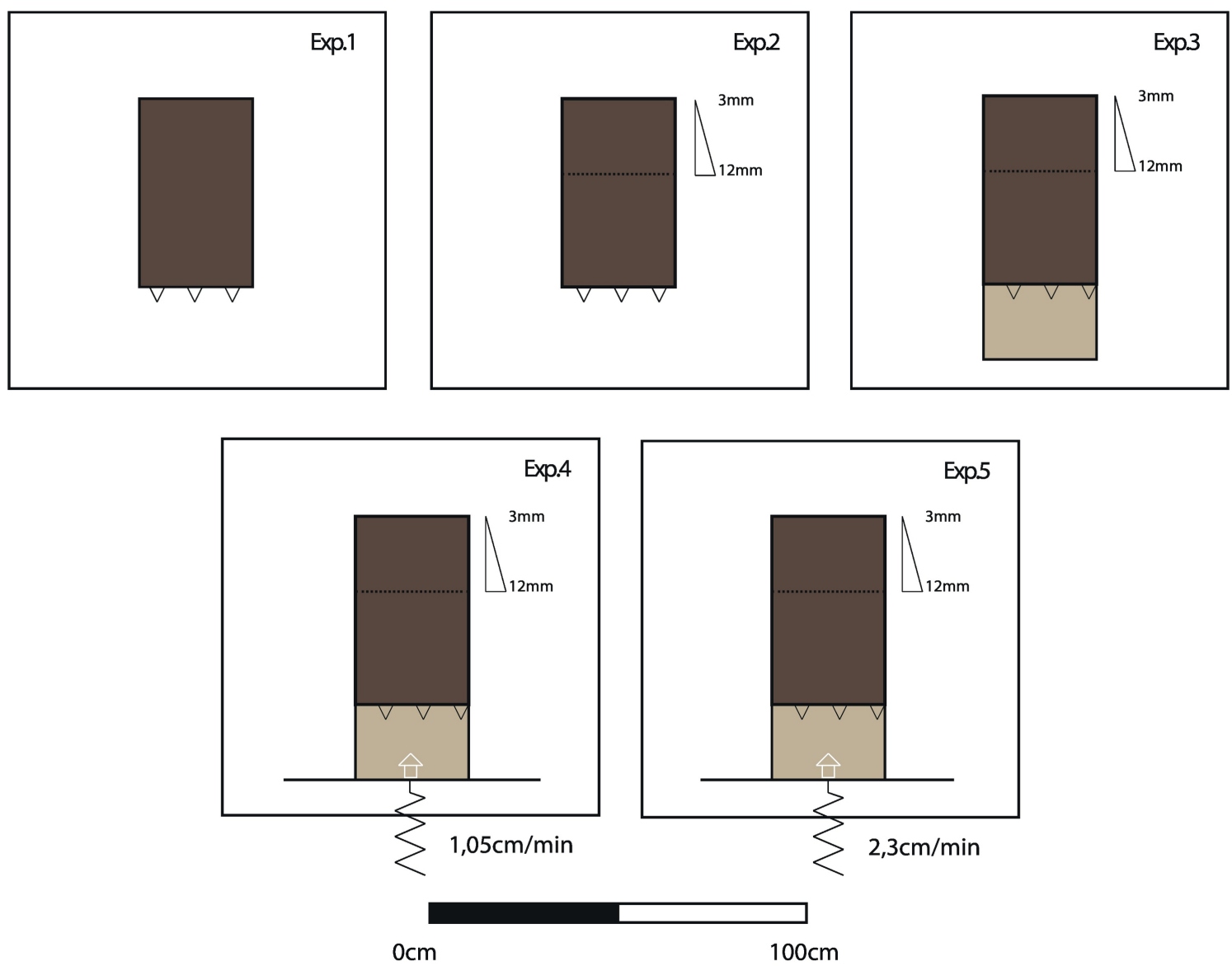

Figure 3 
MODEL 1

MODEL 2

MODEL 3

a)

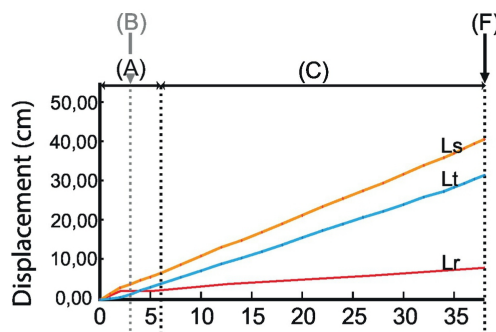

(F) (B)
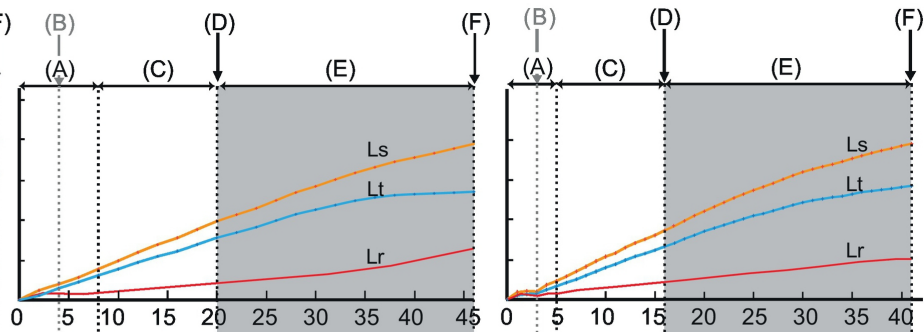

b)
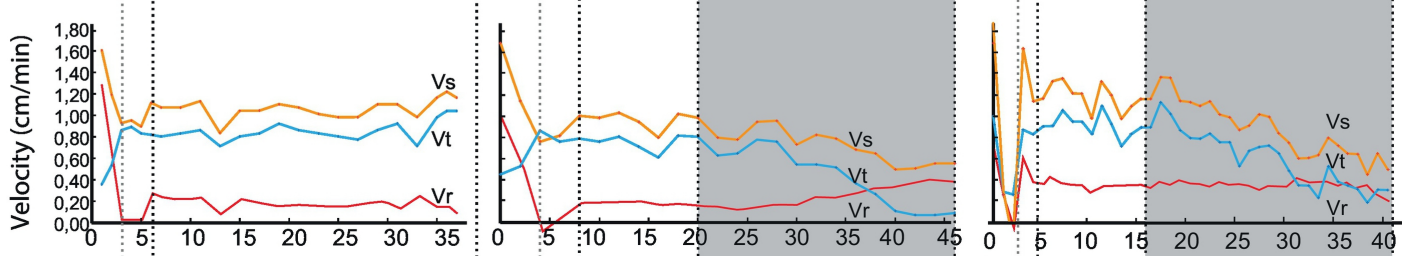

c)
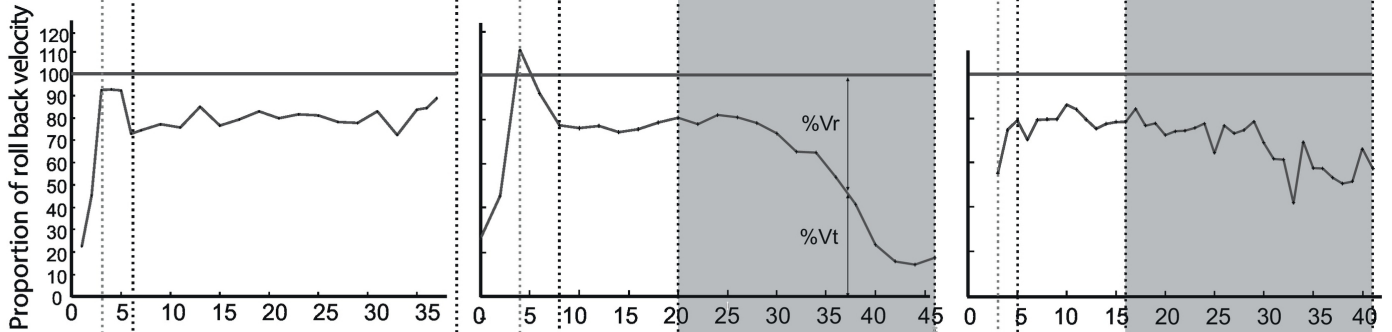

d)
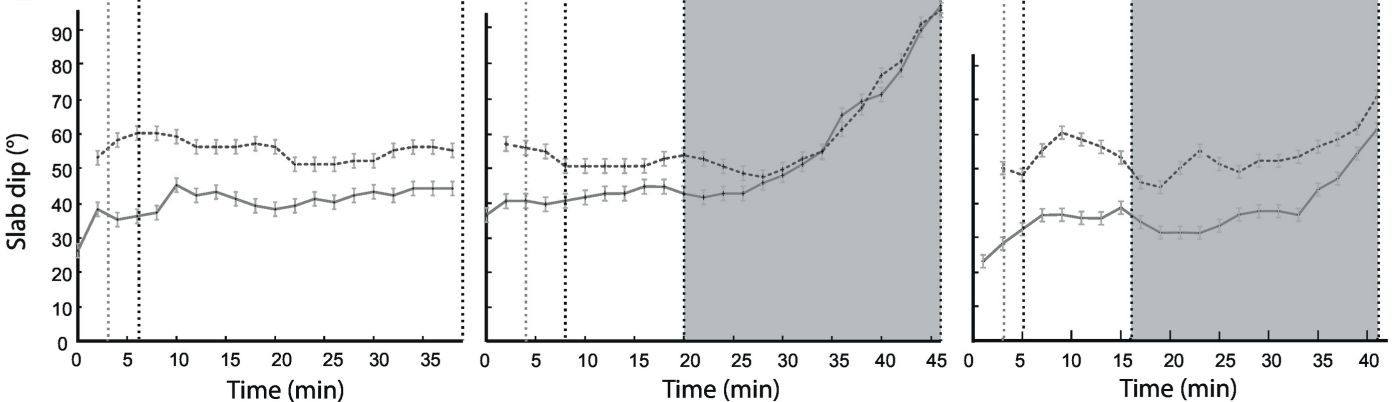

Figure 4 


\section{0 min \\ Bevel \\ $10 \mathrm{~cm}$ \\ Upper mantle \\ Lower mantle}

Oceanic plate

\section{$4 \mathrm{~min}$}

$10 \mathrm{~cm}$

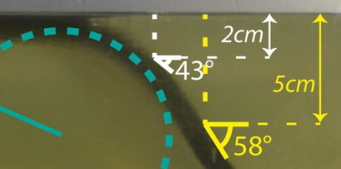

\section{$16 \mathrm{~min}$}

$10 \mathrm{~cm}$

$\sqrt{45^{\circ}}$

\section{$20 \mathrm{~min}$}

$10 \mathrm{~cm}$

$\nabla 45^{\circ}$

$38 \mathrm{~min}$

$46 \mathrm{~min}$

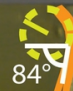

4

$\nabla 54^{\circ}$

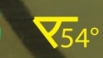


MODEL 4

a)

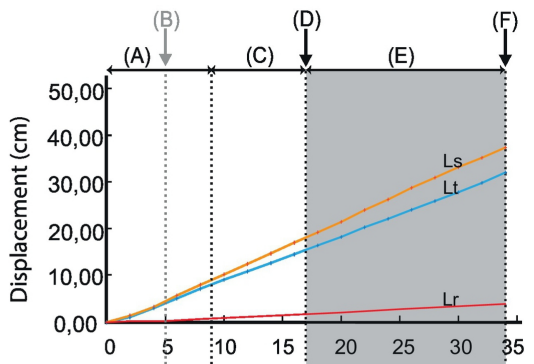

b)

c)

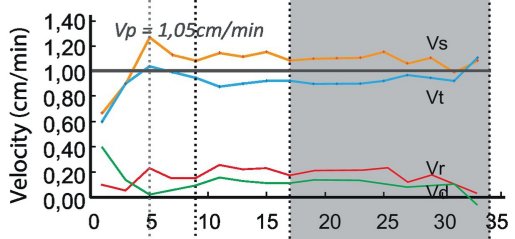

d)
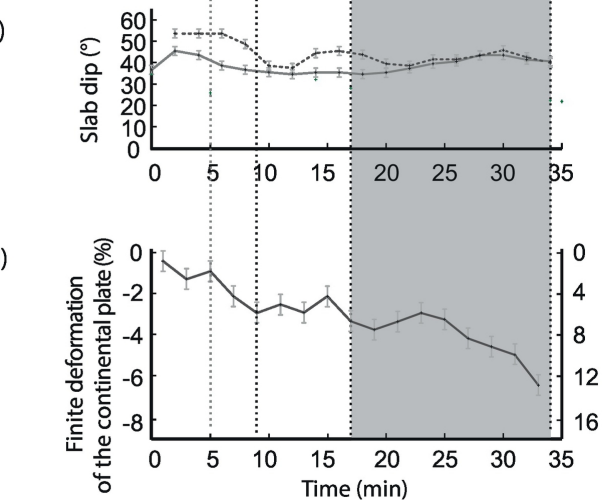

MODEL 5
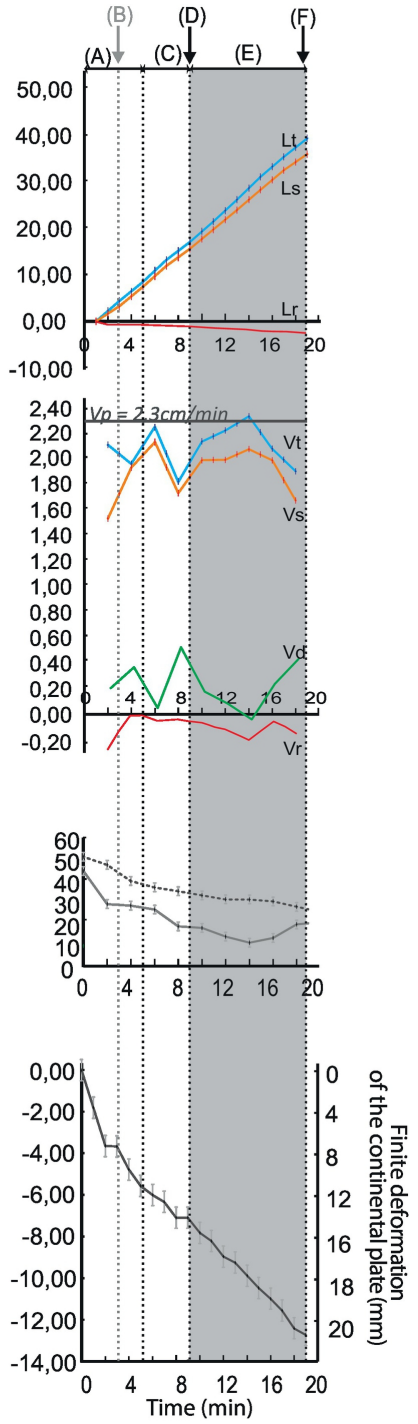

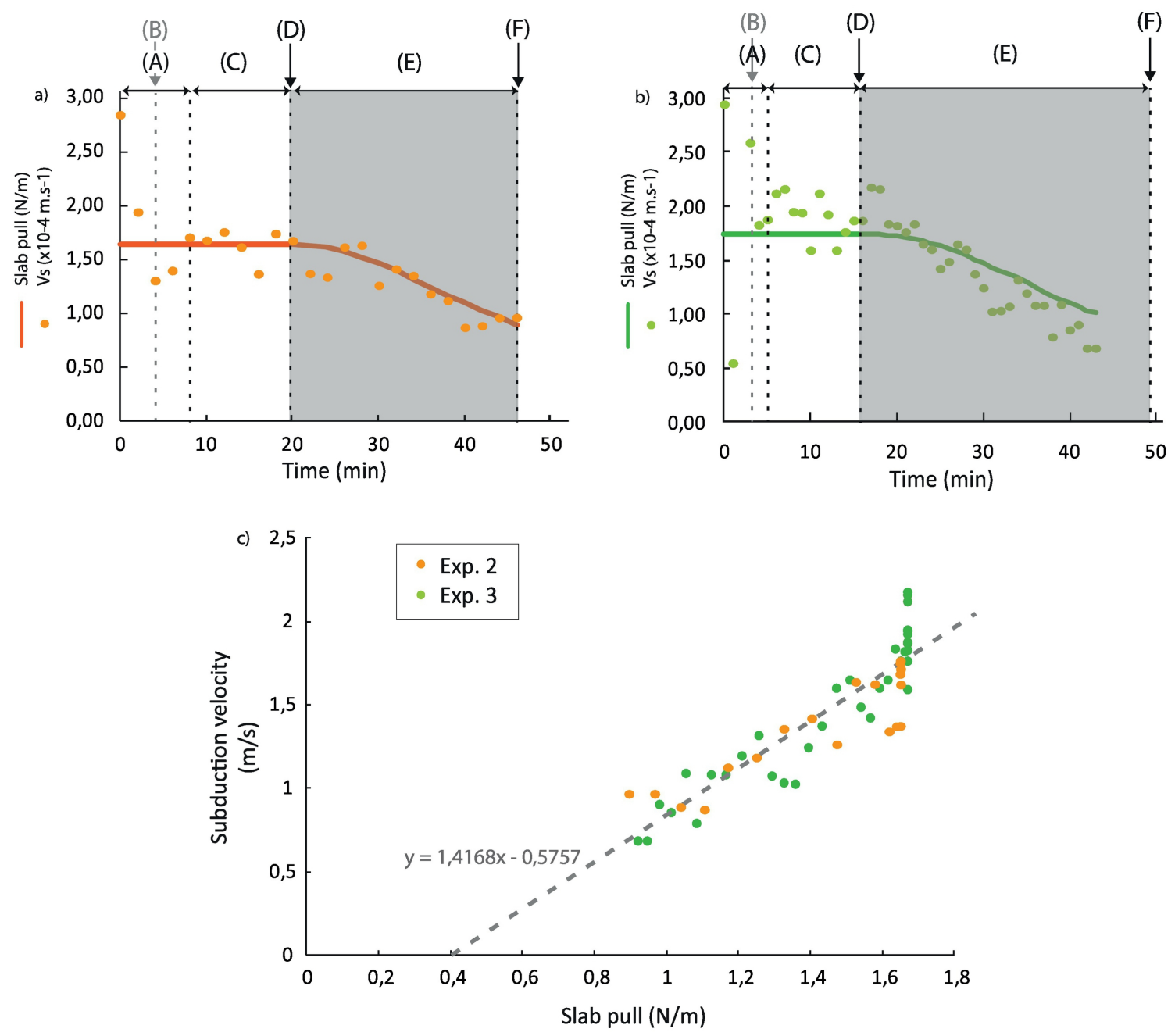

Figure 7 
Time before ridge subduction in nature $(\mathrm{Ma})$

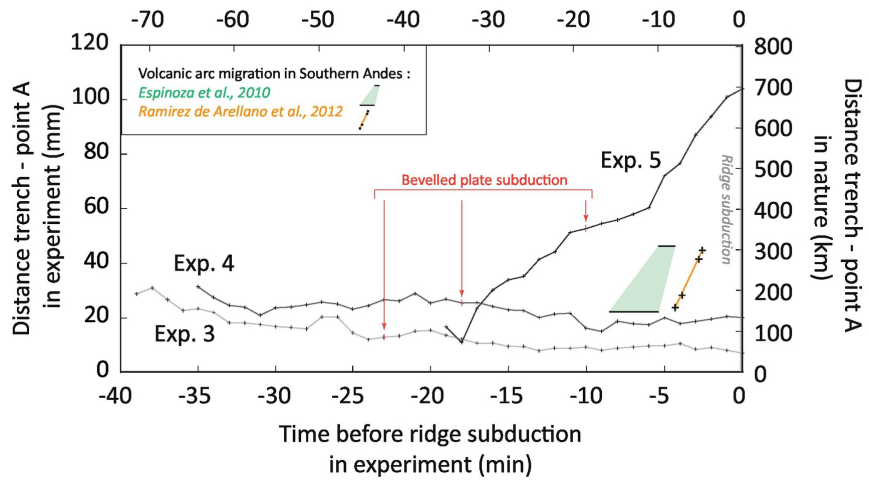

Figure 8 


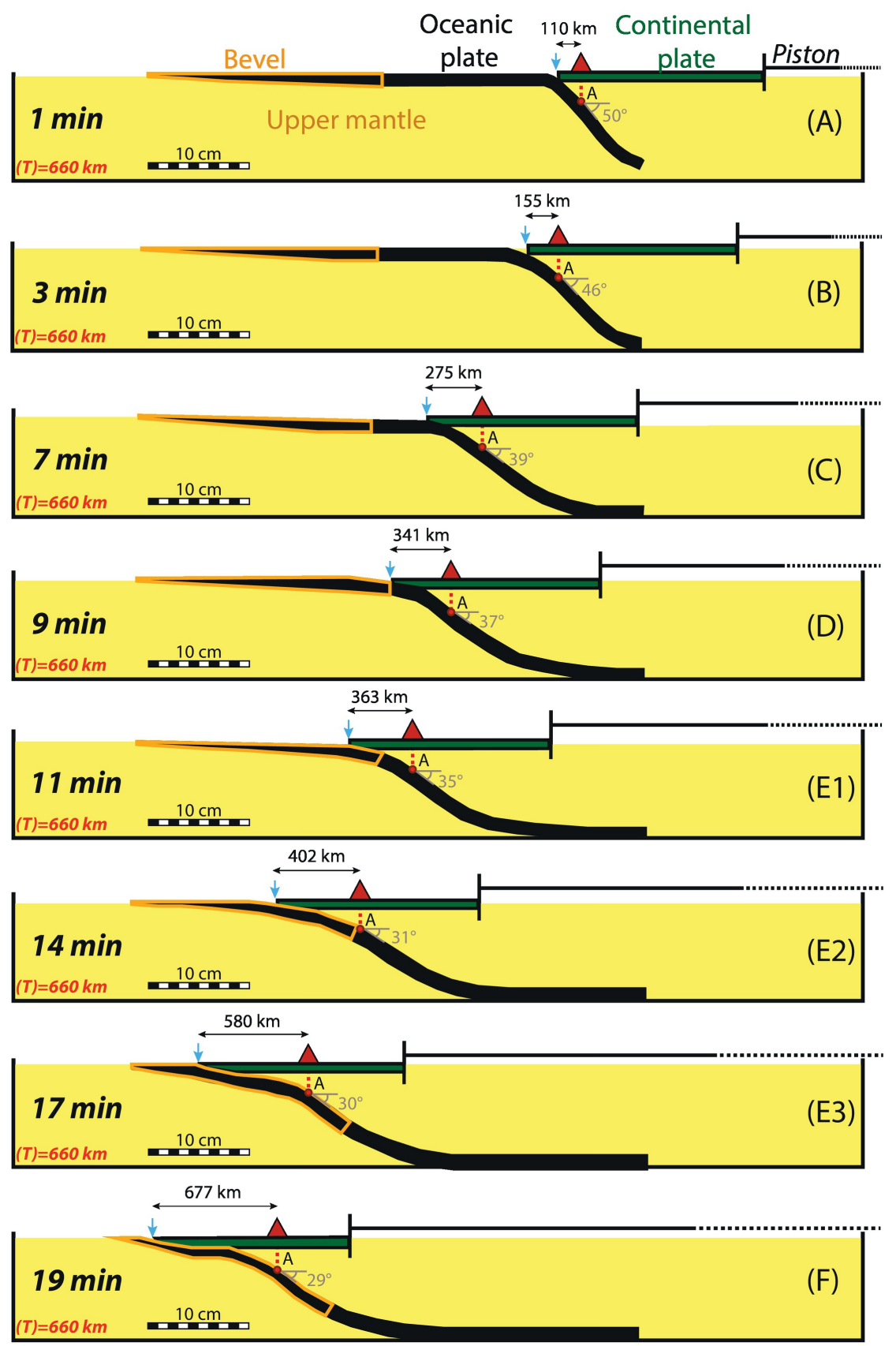




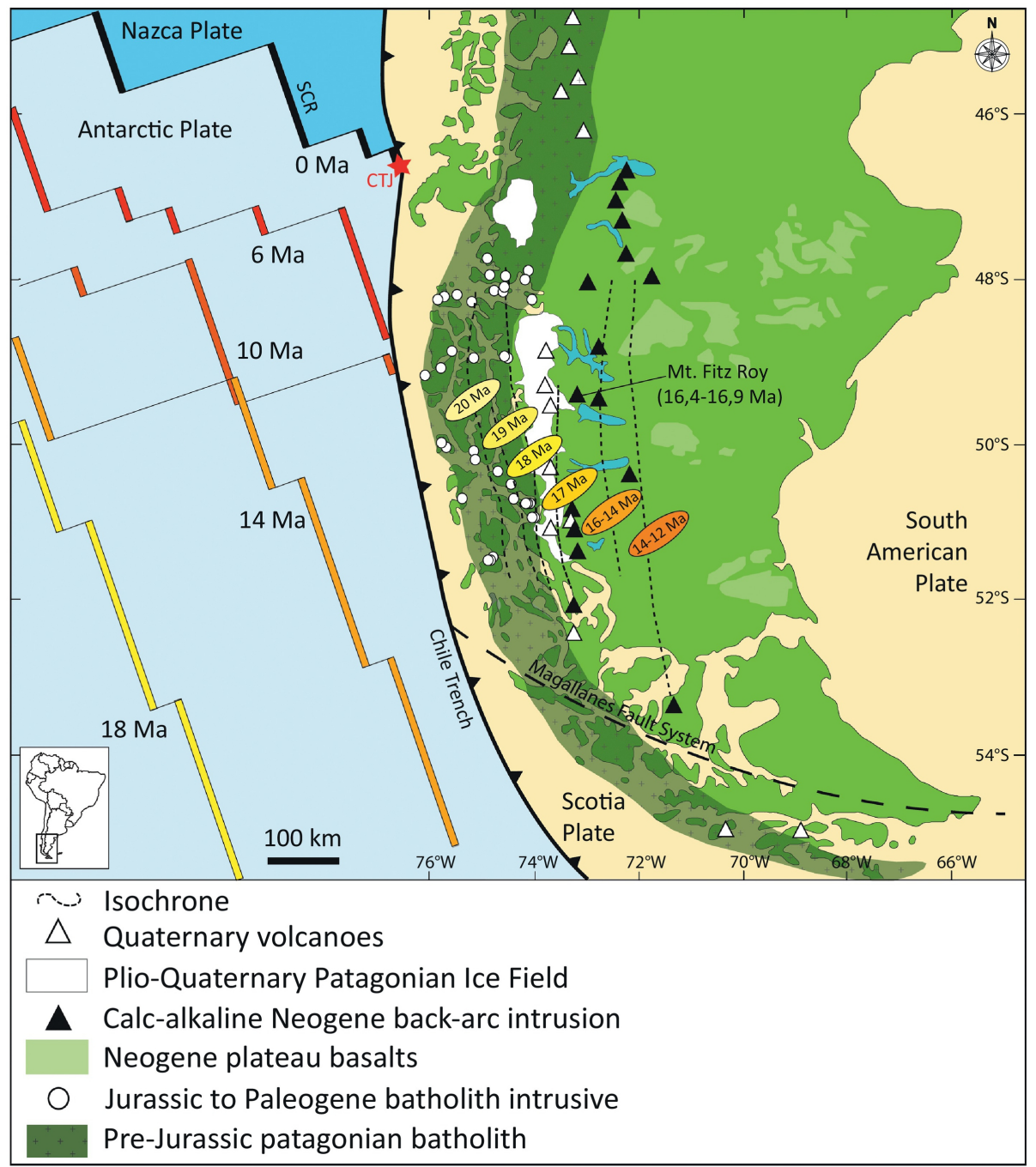


Lateral view of model 1

0 min $\mathrm{min}$

Figure 11 
Top view of model 1
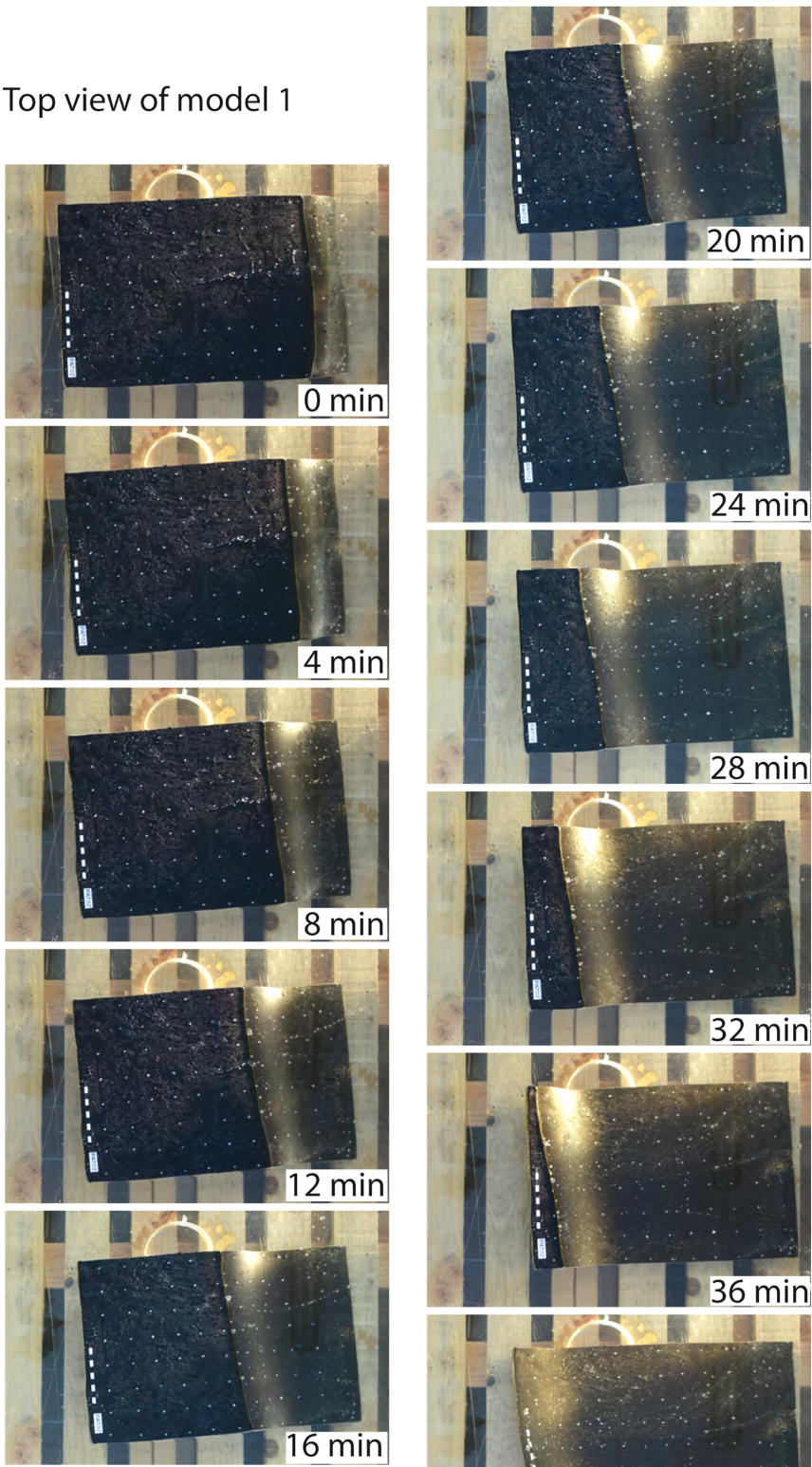

$32 \mathrm{~min}$

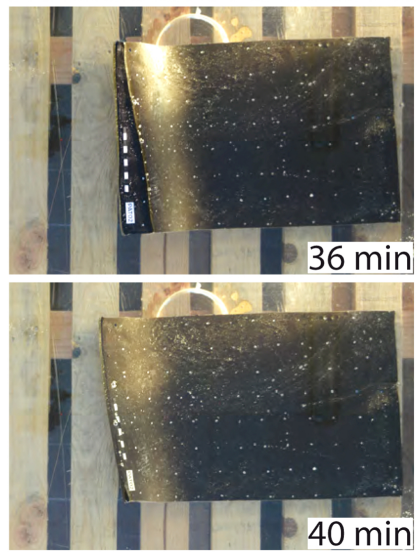

Figure 12 


\section{Lateral view of model 3}
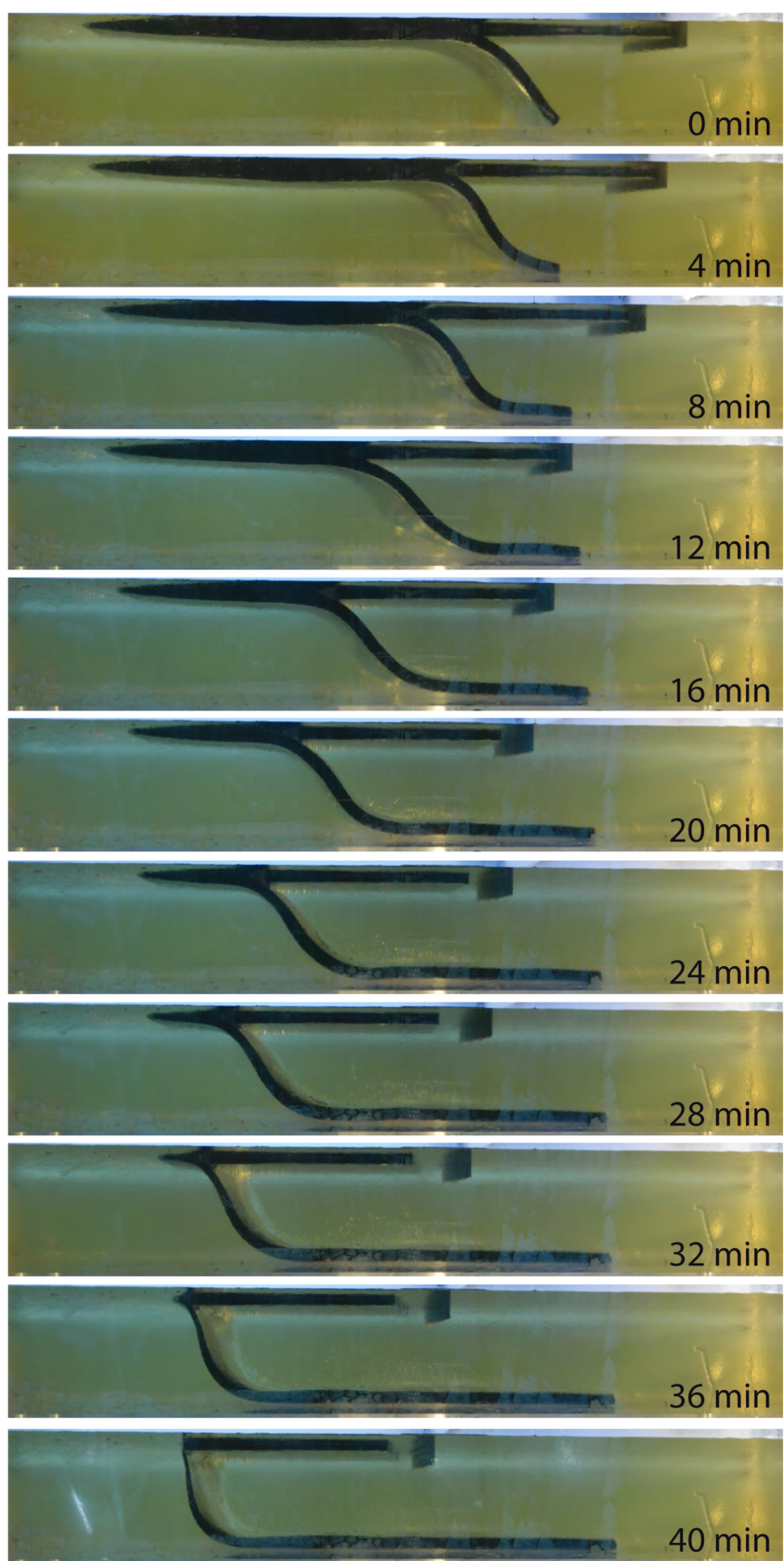

Figure 13 
Sup-5. Top view of model 3
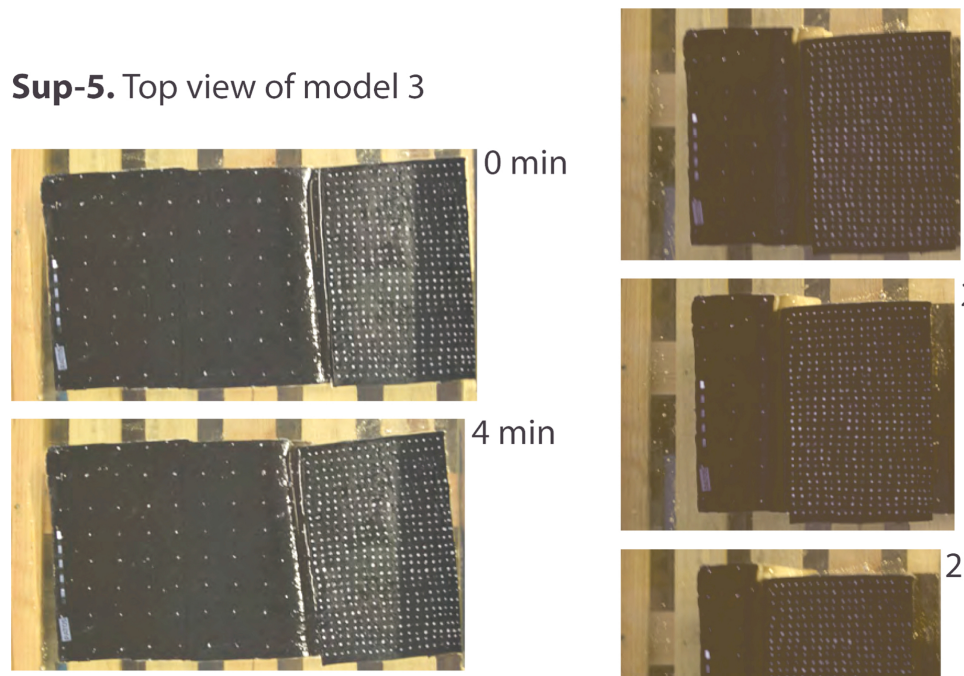

$20 \mathrm{~min}$
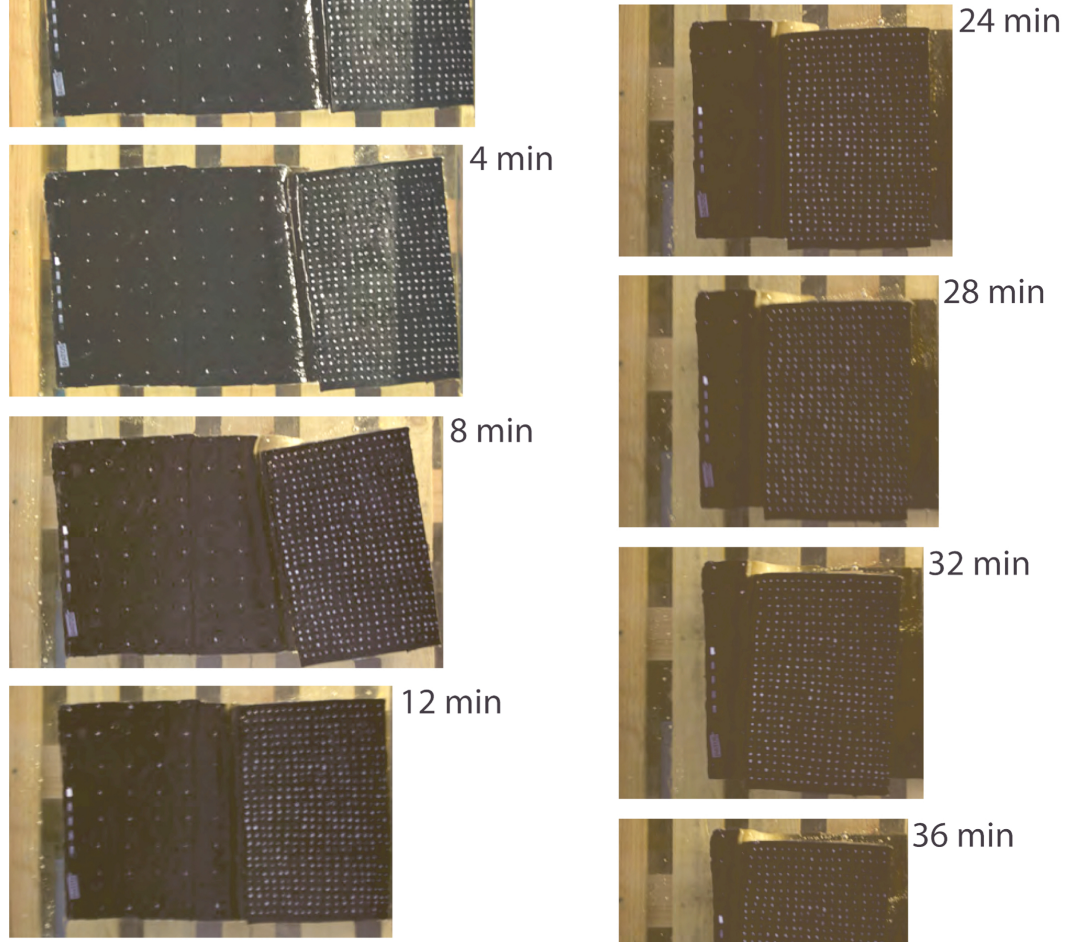

$12 \mathrm{~min}$
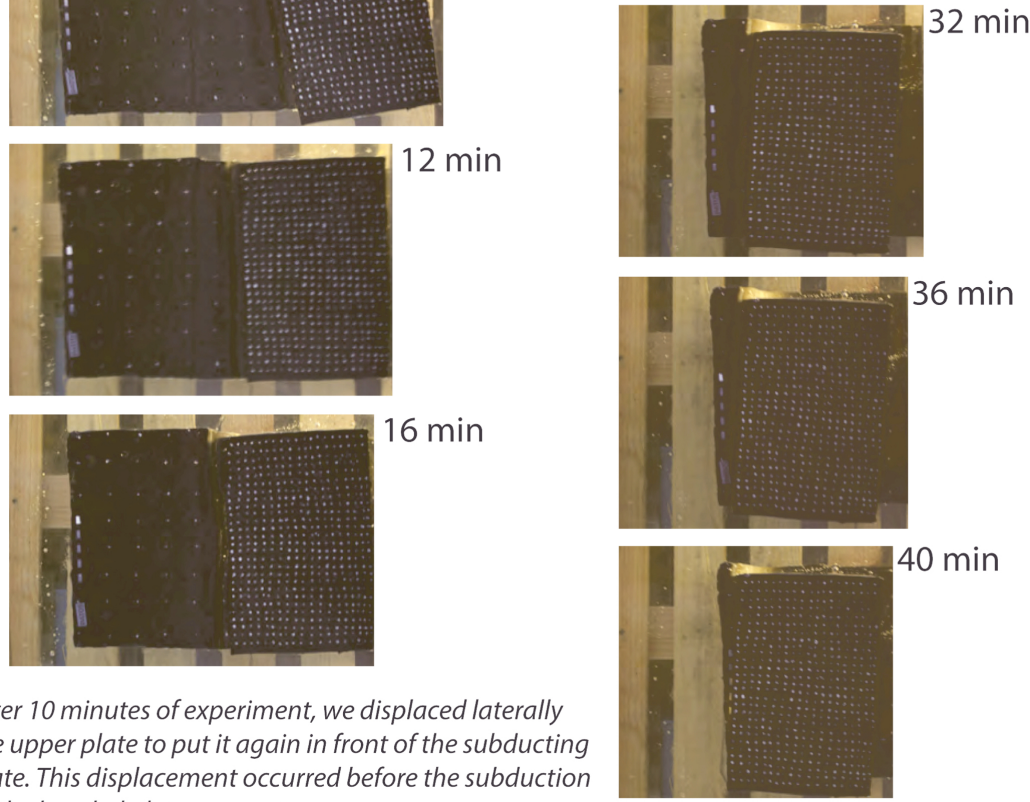

After 10 minutes of experiment, we displaced laterally the upper plate to put it again in front of the subducting plate. This displacement occurred before the subduction of the beveled plate segment. 


\section{Lateral view of model 4}
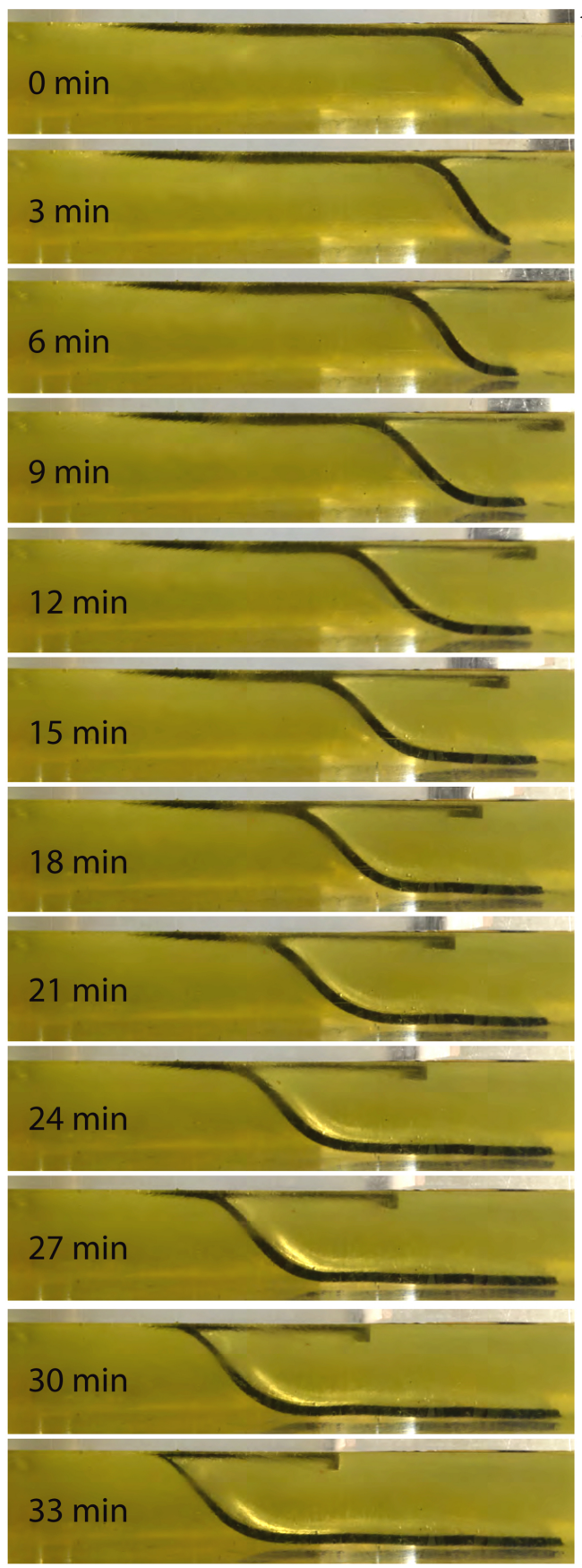

Figure 15 
Top view of model 4
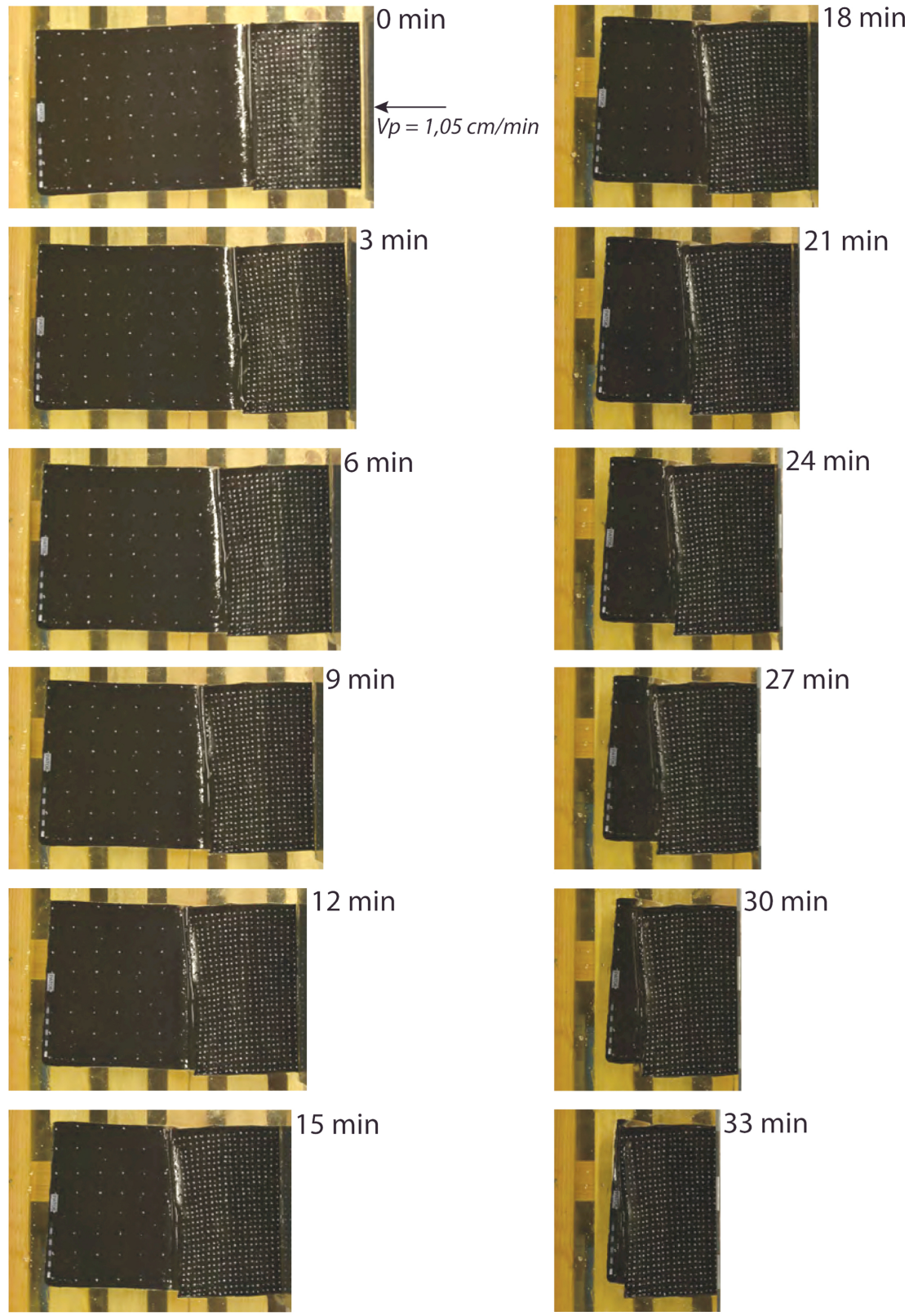

Figure 16 
Lateral view of model 5
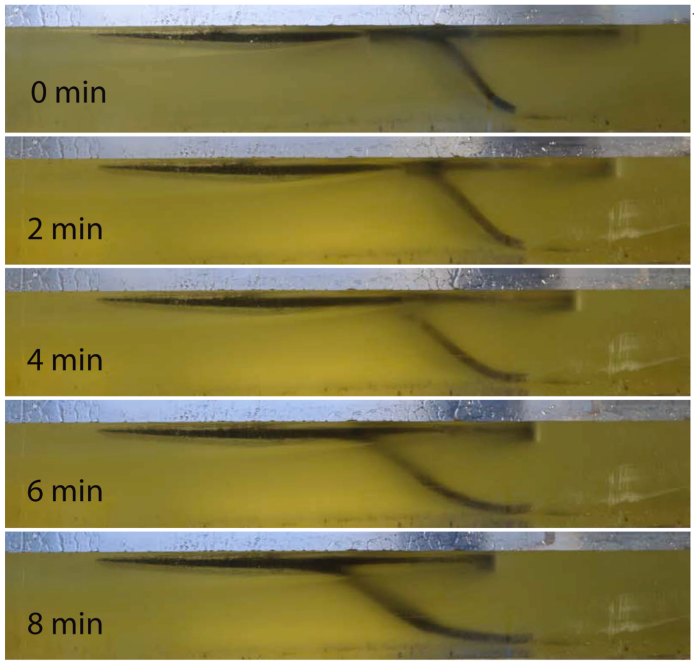

$10 \mathrm{~min}$
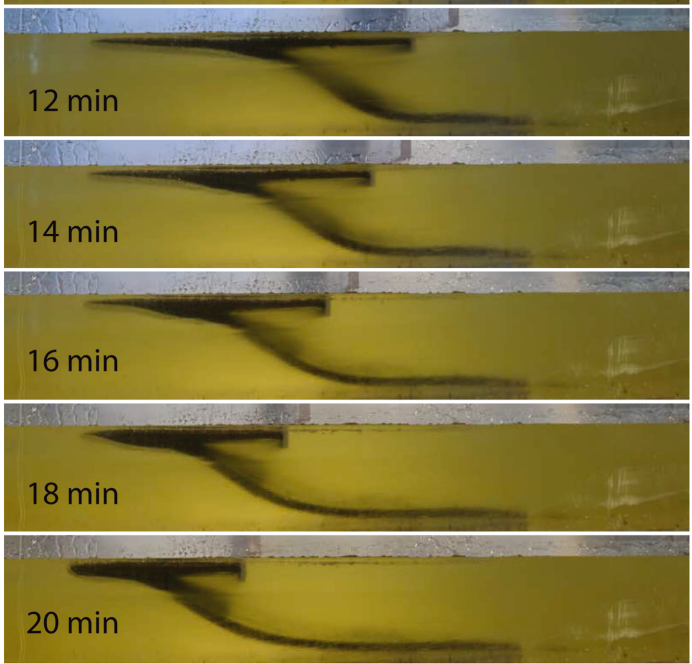

Figure 17 


\section{Top view of model 5}
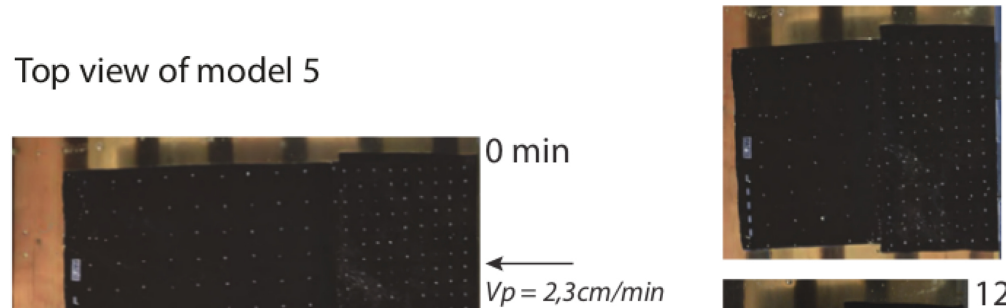

$10 \min$

$$
V p=2,3 \mathrm{~cm} / \mathrm{min}
$$

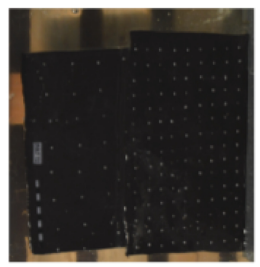

$12 \mathrm{~min}$

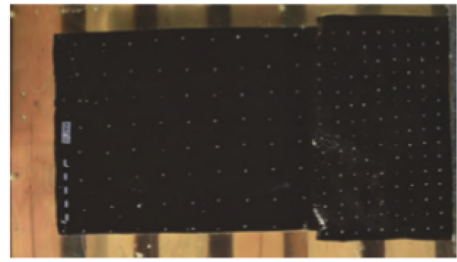

$2 \min$

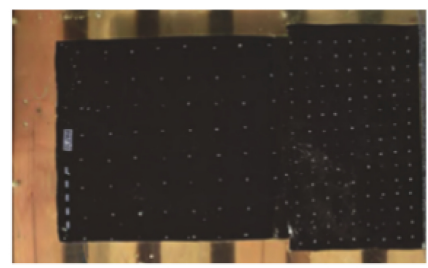

$4 \min$

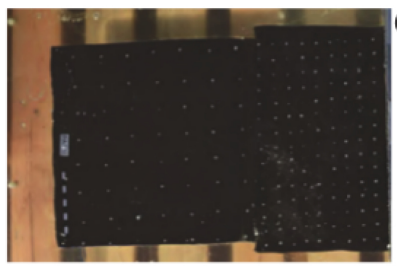

$6 \mathrm{~min}$

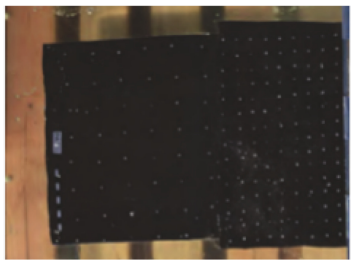

$8 \mathrm{~min}$
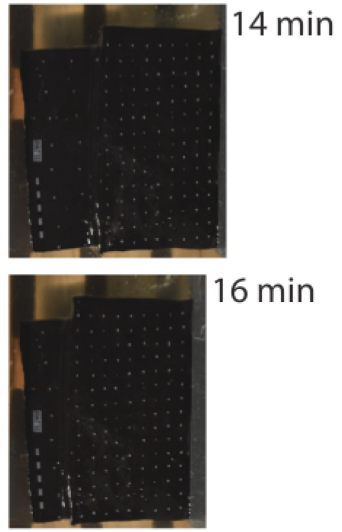

$16 \mathrm{~min}$
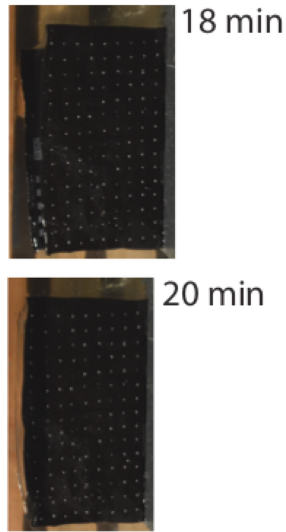

$20 \mathrm{~min}$

Figure 18 